\title{
ZIKA VIRUS INCIDENCE, PREVENTIVE AND REPRODUCTIVE \\ BEHAVIORS: CORRELATES FROM NEW SURVEY DATA*
}

April 2018

\author{
Climent Quintana-Domeque \\ University of Oxford, Oxford, UK
}

José Raimundo Carvalho

Universidade Federal do Ceará, Ceará, Brazil

\author{
Victor Hugo de Oliveira \\ IPECE, Ceará, Brazil
}

\section{Corresponding author:}

Climent Quintana-Domeque

University of Oxford

Department of Economics

Manor Road Building

Mano Road

OX1 3UQ, OXFORD, UK

climent.quintana-domeque@economics.ox.ac.uk

\footnotetext{
* We thank Diego Andre and Abel Brasil for providing excellent research assistance. We also thank Ines Lee, Sonia Oreffice and two anonymous referees for helpful comments and suggestions. The PCSVDF $^{\text {Mulher }}$ survey was funded by the Secretaria Especial de Políticas para as Mulheres - Ministério da Justiça, Brasil. The sponsors of the study had no role in study design, data collection, data analysis, data interpretation, or writing of this article. The authors of this article had full access to all data in the study and had final responsibility for the decision to submit for publication.
} 


\begin{abstract}
During the outbreak of the Zika virus, Brazilian health authorities recommended that pregnant women take meticulous precaution to avoid mosquito bites and that women in general use contraceptive methods to postpone/delay pregnancies. In this article, we present new estimates on the Zika virus incidence, its correlates and preventive behaviors in the Northeast of Brazil, where the outbreak initiated, using survey data collected between March $30^{\text {th }}$ and June $3^{\text {rd }}$ of 2016. The target population were women aged 15-49 in the capital cities of the nine states of the Northeast region of Brazil. We find that more educated women were less likely to report suffering from Zika (or its symptoms) and more likely to report having taken precaution against Zika, such as having used long and light-colored clothes, having used mosquito repellent or insecticides, having used mosquito protective screens or kept windows closed, and having dumped standing water where mosquitoes can breed. In addition, more educated women were more likely to report being informed about the association between Zika and microcephaly and to avoid pregnancy in the last 12 months. Finally, we also find that women who reported experiencing sexual domestic violence in the last 12 months were more likely to report suffering from Zika.
\end{abstract}

Keywords: Zika, education, domestic violence, information, prevention, survey data 


\section{INTRODUCTION}

Zika, a flavivirus, was first identified in the Americas in March 2015, in Bahia, in the Northeast region of Brazil (Campos, Bandeira and Sardi, 2015; Zanluca et al., 2015). In urban and suburban environments, the Zika virus is transmitted in a humanmosquito-human transmission cycle, primarily by Aedes mosquitoes (Petersen et al., 2015). Transmission of Zika from mother to fetus and sexual transmission have both been reported (Calvet et al., 2016; Foy et al., 2011; Jouannic et al., 2016; MMWR, 2016a; MMWR, 2016b; Oliveira et al., 2016; Venturi et al., 2016). Brazil reported an association between Zika infection and Guillian-Barré syndrome in July 2015, and an association between Zika infection and microcephaly in October 2015 (WHO, 2016). ${ }^{1}$

Kindhauser et al. (2016) describe the spread of the Zika virus worldwide since 1947. The authors observe that Zika infection in humans has changed in character while expanding in geographical range. Between 1947 and 2007, Zika caused mild illness across equatorial African and Asian countries. From 2007 onwards, Zika has caused large outbreaks in previously unexposed populations, and from 2013 onwards, Zika outbreaks have been linked to neurological disorders. The authors also argue that future transmission of Zika is likely to coincide with the global distribution of Aedes vectors.

In the Americas, Zika was probably introduced between May and December 2013, and had been circulating in Brazil earlier than the first Zika virus infection case was reported in 2015 (Faria et al., 2016). International events, such as the catholic event "World Youth Day" in July 2013, the World Cup in 2014, and the Canoeing Championship in Rio de Janeiro in 2014, are likely to explain the introduction of such arbovirus in Brazil (Faria et al., 2016). Using the Global Epidemic and Mobility Model, Zhang et al. (2017) show that Zika was introduced in Brazil probably in Rio de Janeiro,

\footnotetext{
${ }^{1}$ http://www.who.int/mediacentre/factsheets/zika/en/, last accessed: April 4, 2018.
} 
Brasília (Federal District), Salvador and Fortaleza. Faria et al. (2017) provide evidence of the role of the Northeast region of Brazil in the establishment of the Zika virus in the Americas.

Brazilian health authorities have recommended that pregnant women take meticulous precaution to avoid mosquito bites and that women in general use contraceptive methods to postpone/delay pregnancies. The emergency protocol, published after the Ministry of Health declared the state of emergency in public health of national interest in November $11^{\text {th }}, 2015$, focused not only on pregnant women and their infants, but also on women in childbearing age. ${ }^{2}$ Public health authorities explicitly recommended to increase the access to contraceptive methods in the public health system, and to strengthen preconception counseling in order to inform women who want to get pregnant about the current situation of the cases of microcephaly in the country. On February $1^{\text {st }}$, 2016, the WHO declared the Zika outbreak as a Public Health Emergency of International Concern (WHO, 2016). By August $25^{\text {th }}$ of 2017,48 countries and territories in the Americas confirmed autochthonous, vector-borne transmission of Zika virus disease, while five countries reported sexually transmitted Zika cases (PAHO, 2017). ${ }^{3}$

A potential causal relationship between Zika infection during pregnancy and microcephaly, and other serious brain anomalies, was firstly reported in May 2016 by Rasmussen et al. (2016). Posterior case-control studies support this causal relationship. For instance, evidence has shown that the microcephaly epidemic is a result of congenital Zika infection in Brazil (Araújo et al., 2016). Besides, children with congenital Zika but normal head size at birth can develop microcephaly and have

http://portalarquivos2.saude.gov.br/images/PROTOCOLO\%20DE\%20ATENDIMENTO\%20PARA\%20 MICROCEFALIA.pdf, last accessed: April $4^{\text {th }}, 2018$.

${ }^{3} \mathrm{http}: / / \mathrm{www}$.paho.org/hq/index.php?option=com_content\&id=11599\&Itemid=41691, last accessed: April $4^{\text {th }}, 2018$. 
significant neurologic sequelae after birth (van der Linden et al., 2016). In November $18^{\text {th }}$ of 2016, the Emergency Committee of the World Health Organization felt that Zika and associated consequences no longer represented a Public Health Emergency of International Concern because there was enough scientific evidence of the link between Zika virus infection and microcephaly at that time. ${ }^{4}$ Recent research has made progress in sequencing the Zika genome (Worobey, 2017) and discovering a vaccine to protect human from Zika infection (Abbink et al., 2016).

However, diagnosing Zika is complicated for several reasons (Petersen et al., 2016). The fact that dengue and chikungunya, which result in similar clinical pictures, have both been epidemic in Brazil confound clinical diagnoses (Fauci and Morens, 2016; Petersen et al., 2016). ${ }^{5}$ Moreover, because Zika is closely related to dengue, serologic samples may cross-react in test for either virus (Fauci and Morens, 2016; Petersen et al., 2016). As emphasized by Possas (2016), understanding the social, economic, and anthropological aspects of the vulnerable population is of paramount importance because a pathogen requires a receptive population to cause disease.

In this article, we present new estimates of the Zika virus incidence, its correlates and preventive behaviors in the Northeast of Brazil, where the outbreak initiated, using survey data collected through the PCSVDF ${ }^{\text {Mulher }}$ (Pesquisa de Condições Socioeconômicas e Violência Doméstica e Familiar contra a Mulher) survey. This survey was conducted between March $30^{\text {th }}$ and June $3^{\text {rd }}$ of 2016 and its target population were women aged 15-49 in the capital cities of the nine states of the Northeast region of Brazil. The main objectives of the PCSVDF ${ }^{\text {Mulher }}$ survey were to measure the causes and consequences of domestic (intimate partner) violence in Brazil. Given the Zika outbreak during the development of the PCSVDF ${ }^{\text {Mulher }}$ survey, it was decided to incorporate a

\footnotetext{
${ }^{4}$ http://www.who.int/mediacentre/news/statements/2016/zika-fifth-ec/en, last accessed: April $4^{\text {th }}, 2018$.

5 http://iris.paho.org/xmlui/handle/123456789/33895, last accessed: April $4^{\text {th }} .2018$.
} 
battery of questions which shall provide useful information regarding the incidence of Zika, its correlates and preventive behaviors.

We study Zika incidence and symptoms, behavioral/preventive responses to Zika, knowledge on Zika and microcephaly, pregnancy status and contraceptive behavior. We find that more educated women were less likely to report suffering from Zika (or its symptoms) and more likely to report having taken precaution against Zika, such as having used long and light-colored clothes, having used mosquito repellent or insecticides, having used mosquito protective screens or kept windows closed, and having dumped standing water where mosquitoes can breed. In addition, more educated women were more likely to report being informed about the association between Zika and microcephaly and to avoid pregnancy in the last 12 months. Finally, we also find that women who reported experiencing sexual domestic violence in the last 12 months were more likely to report suffering from Zika (or its symptoms). These findings may be useful in enhancing family planning and reproductive health policies in Brazil, and more generally, in a context of health shocks or epidemics.

Our study can provide guidance to shape the Family Health Program, which provides primary health care services at the community level, by identifying the most exposed (and vulnerable) sociodemographic groups to the Zika epidemic, and their main preventive and behavioral responses. One of these responses is the postponement of pregnancy, which suggests a potential increase in the demand for both family planning advice in the primary health care service and contraceptives.

Finally, our study can contribute to the public policy of endemic disease control, since we also investigate the correlates of the likelihood of visits by endemic disease control agents. The control of Aedes aegypti has been intensified since the declaration of public health emergency by the Ministry of Health at the end of 2015, including the 
mobilization of armed forces to survey households (Augusto et al., 2016). However, the vector control program has not prevented the spread and introduction of diseases transmitted by the Aedes aegypti, not even in areas with a well-organized public health system (Castro, 2016).

The rest of the paper is organized as follows. Section 2 contains the data description. Section 3 presents our results. Section 4 discusses our findings in the light of previous estimates. Section 5 concludes.

\section{DATA}

This study uses data from the PCSVDF ${ }^{\text {Mulher }}$ (Pesquisa de Condições Socioeconômicas e Violência Doméstica e Familiar contra a Mulher) survey, which was conducted by Datainfo $^{6}$-a company with previous experience in victimization surveys- between March $30^{\text {th }}$ and June $3^{\text {rd }}$ of $2016 .^{7}$ A description of the sample design and data entry of the PCSVDF ${ }^{\text {Mulher }}$ is provided in the online appendix.

In Table 1 we compare the average characteristics of the respondents in the PCSVDF $^{\text {Mulher }}$ with those of women aged 15-49 from the Pesquisa Nacional por Amostra de Domicílios Contínua - PNADC (1st quarter, 2016), a national representative household survey carried out by the Instituto Brasileiro de Geografia e Estatística (IBGE). ${ }^{8}$ The total sample size in the PCSVDF $^{\text {Mulher }}$ is 10,094 women in the nine state capitals of Northeastern Brazil, which is very close to the number of sampled women in

\footnotetext{
${ }^{6}$ http://www.datainfo.inf.br, last accessed: April $4^{\text {th }}, 2018$.

${ }^{7}$ Ethical and safety guidelines for the conduct of this research were developed and were adhered to. These emphasized individual informed consent and the importance of ensuring confidentiality and privacy, both as a mean to protect the safety of respondents and field staff, and to improve the quality of the data. Ethics permission for the study was obtained from the Brazilian Scientific Ethical Committee (Approval Number 53690816.5.0000.5054).

${ }^{8}$ Currently, there are two versions of the PNAD: i) PNAD Contínua, (or PNADC) collects data in each trimester of the year (since 2012); ii) PNAD (the standard version) collects data once a year (in September of each year, since 1977).
} 
the PNADC/IBGE, 10,988. In general, the distribution of characteristics is very similar across respondents in the PCSVDF ${ }^{\text {Mulher }}$ and the PNADC.

\section{[Insert Table 1 about here]}

\section{RESULTS}

\subsection{Stylized facts}

Table 2 displays information on the incidence of Zika and its symptoms, preventive behaviors, and reproductive behaviors. The table allows us to document the following stylized facts:

\section{[Insert Table 2 about here]}

\section{A. Incidence of Zika and symptoms}

1. $23.29 \%$ of women aged 15-49 report having been diagnosed with Zika in the past 12 months.

2. $34.8 \%$ of women aged 15-49 report having had mild fever, rash, and/or joint pain (typical symptoms associated to Zika) in the past 12 months.

3. $48.59 \%$ of women aged 15-49 report that there has been a Zika case in their households in the past 12 months.

4. $67.2 \%$ of women aged 15-49 report having heard/known about a Zika case in their neighborhood in the past 12 months.

5. 59.3\% of women aged 15-49 report having received the visit of endemic diseases (dengue, Zika, etc.) control agents in the past 12 months.

\section{B. Preventive behaviors}

6. $8.93 \%$ of women aged 15-49 report having used long and light-colored clothes frequently or always, even during hot days, in the past 12 months. 
7. $20.77 \%$ of women aged 15-49 report having used mosquito repellent or insecticides frequently or always in the past 12 months.

8. $13.96 \%$ of women aged 15-49 report having used mosquito protective screens or kept windows closed frequently or always in the past 12 months.

9. $78.61 \%$ of women aged $15-49$ report having dumped standing water where mosquitoes can breed frequently or always in the past 12 months.

\section{Reproductive behaviors}

10. $96.12 \%$ of women aged 15-49 report knowing that Zika is associated with malformation in newborns (microcephaly).

11. 4.29\% of women aged 15-49 report being currently pregnant; 0.49\% of women 15-49 do not know/maybe.

12. 50.88\% of women aged 15-49 report having used any contraceptive (or tried in any way) to delay or avoid getting pregnant in the last 12 months; among those (n=789), $18.32 \%$ report this was motivated because of the Zika epidemic.

\subsection{Conditional correlates: multivariate logistic regressions}

In Table 3 we study the correlates of Zika incidence as measured by five different indicators: reporting to have been diagnosed with Zika in the last 12 months, reporting to have suffered from typical Zika symptoms (e.g., mild fever, rash, and/or joint pain) in the last 12 months, reporting to have had a Zika case in their household in the past 12 months, reporting to have heard/known about a Zika case in their neighborhood in the past 12 months, and reporting to have received the visit of endemic diseases (dengue, Zika, etc.) control agents in the last 12 months. ${ }^{9}$ Table B1 in the

\footnotetext{
${ }^{9}$ Endemic disease control agents (Agentes de Controle de Endemias) are professionals responsible for sanitary inspections in dwellings, deposits, vacant lands and commercial establishments. They search for endemic foci. They must carefully conduct inspections of water tanks, gutters and roofs, and apply larvicides and/or insecticides. They must also provide guidelines for the prevention and treatment of
} 
online appendix displays the pairwise correlation coefficients between these (and additional) variables. For instance, the estimated standard Pearson correlation coefficient between reporting being diagnosed with Zika and reporting Zika symptoms is 0.646 ( $\mathrm{p}$-value $<0.01)$.

We run multivariate logistic regressions for each of these binary variables on women's characteristics and (state) capital fixed effects. ${ }^{10}$ The vector of women's characteristics includes: age binary indicators $(20-24,25-29,30-34,35-39,40-44,45-$ 49), race binary indicators (Black, Brown, Asian/Indigenous) and educational binary indicators (fundamental, high-school, college). ${ }^{11}$ The table reports the odds-ratio (OR) for each logit coefficient (i.e., the logit coefficient exponentiated).

The results displayed in Table 3 reveal that women with high-school were less likely to report to have been diagnosed with Zika in the last 12 months $(\mathrm{OR}=0.783$, pvalue $<0.01)$ and to have suffered from Zika symptoms $(\mathrm{OR}=0.817$, p-value $<0.01)$ than those with no (fundamental) education; qualitatively similar, but quantitatively stronger, results are found for college-educated women $(\mathrm{OR}=0.542$, $\mathrm{p}$-value $<0.01$ and $\mathrm{OR}=0.519$, p-value<0.01). Moreover, college-educated women were less likely to report to have had a Zika case in their household in the past 12 months $(\mathrm{OR}=0.824$, p-value $<0.05)$. Finally, education was unrelated to the likelihood of reporting to have heard/known about a Zika case in their neighborhood in the past 12 months $\left(\chi^{2}(3)=3.46\right.$, pvalue $=0.3256$ ), but was positively related to the likelihood of reporting to have received the visit of endemic disease control agents $(\mathrm{OR}=1.24$ and $\mathrm{p}$-value $<0.01$ for highschool). Perhaps the main message from Table 3 is that more educated women were less

infectious diseases and perform the census of animals. In many cases, they are the first point of contact in cases of epidemics in Brazil.

${ }^{10}$ Section B of the online appendix reports linear multivariate regressions (linear probability models).

${ }^{11}$ We classify education into four categories: no fundamental $=$ no schooling or some fundamental education; fundamental education = fundamental education or some high-school; high-school = highschool or some college; college $=$ college or graduate studies. The reference categories are women aged 15-19, with no fundamental education, white and living in Teresina, Piauí state capital. 
likely to report suffering from Zika (or its symptoms) or having a Zika case in their households. The negative association between education and the likelihood of reporting suffering from Zika (or its symptoms) is consistent with the well-documented positive association between education and health. ${ }^{12}$

\section{[Insert Table 3 about here]}

In Table 4 we investigate correlates of four Zika preventive behaviors, namely, having used long and light-colored clothes, even during hot days, in the last 12 months, having used mosquito repellent or insecticides in the last 12 months, having used mosquito protective screens or kept windows closed in the last 12 months, and having dumped standing water where mosquitoes can breed in the last 12 months. ${ }^{13}$ We find that more educated women were more likely to follow preventive measures against Zika. In particular, we observe that women with fundamental education were more likely to report having used long and light-colored clothes, even during hot days, in the last 12 months, $(\mathrm{OR}=1.38$, p-value $<0.05)$ and to have used mosquito repellent or insecticides in the last 12 months $(\mathrm{OR}=1.43$, p-value<0.01) than those with no (fundamental) education; stronger results are found for high-school $(\mathrm{OR}=1.54$, $\mathrm{p}$ value $<0.01$ and $\mathrm{OR}=1.90, \mathrm{p}$-value $<0.01)$ and college-educated women $(\mathrm{OR}=2.30$, $\mathrm{p}$ value $<0.01$ and $\mathrm{OR}=2.64$, $\mathrm{p}$-value $<0.01$ ). Regarding the use of mosquito protective screens or keeping windows closed in the last 12 months, high-school and collegeeducated women were more likely to report having used them with respect to women with no (fundamental) education $(\mathrm{OR}=1.20$, $\mathrm{p}$-value $<0.05$ and $\mathrm{OR}=1.58$, $\mathrm{p}$-value $<0.01)$. Finally, educated women (fundamental, high-school, and college) were more likely to report having dumped standing water where mosquitoes can breed in the last 12 months

\footnotetext{
${ }^{12}$ Galama, Kippersluis and Lleras-Muney (2018) offer a systematic review of the literature on the effect of education on health.

${ }^{13}$ The estimated standard Pearson correlation coefficients between these four Zika preventive behaviors are displayed in Table B1 in the online appendix.
} 
$(\mathrm{OR}=1.31, \mathrm{p}$-value $<0.01 ; \quad \mathrm{OR}=1.46, \quad \mathrm{p}$-value $<0.01 ; \quad \mathrm{OR}=1.41, \mathrm{p}$-value $<0.01)$. The positive association between education and Zika preventive behaviors is consistent with experimental evidence showing that lack of knowledge of malaria transmission and prevention is a barrier to insecticide-treated nets adoption (Rhee et al., 2005).

\section{[Insert Table 4 about here]}

In Table 5 we investigate the correlates of knowing that the Zika virus is associated with malformation in newborns, being currently pregnant and having used any contraceptive (or tried in any way) to delay or avoid getting pregnant in the last 12 months. Two interesting patterns emerge from this table: first, educated women were more likely to report to know that Zika is associated with malformation in newborns $(\mathrm{OR}=1.66$ and $\mathrm{p}$-value $<0.01$ for high-school, $\mathrm{OR}=1.65$ and $\mathrm{p}$-value $<0.05$ for college education) than those with no (fundamental) education, although one must bear in mind that $96 \%$ of women report knowing that Zika virus may cause microcephaly. ${ }^{14}$ Second, education was positively related to contraceptive behavior $(\mathrm{OR}=1.22$ and $\mathrm{p}$-value $<0.01$ for high-school, $\mathrm{OR}=1.37$ and $\mathrm{p}$-value $<0.01$ for college education) ${ }^{15}$

\section{[Insert Table 5 about here]}

\subsection{Additional correlates: the role of domestic violence}

As discussed in the introduction, the main objectives of the PCSVDF ${ }^{\text {Mulher }}$ survey were to measure the causes and consequences of domestic (and intimate partner) violence. In this subsection we replicate Tables 3, 4 and 5 adding exposure to intimate partner violence in the last 12 months. Among those women who accepted to participate in the $\operatorname{PCSVDF}^{\text {Mulher }}, 7,411$ were eligible to answer the section on Experience of

\footnotetext{
${ }^{14}$ Both women with high-school and women with college were about 2 percentage points more likely to report knowing that Zika virus may cause microcephaly than those with no (fundamental) education. See Table B4 in the online appendix.

${ }^{15}$ Education was unrelated to the likelihood of being currently pregnant $\left(\chi^{2}(3)=3.88\right.$, $p$-value $\left.=0.2749\right)$.
} 
Violence (partner/ex-partner), and 5,858 of them answered this section. Hence our original sample size decreases by about $40 \%$.

The PCSVDF ${ }^{\text {Mulher }}$ survey provides information regarding the following types of domestic violence: 1) psychological/emotional violence; 2) physical violence; and 3) sexual violence. Emotional domestic violence happens when women have been insulted, humiliated, scared, intimidated, or threatened by their respective partners (or ex-partners). Physical domestic violence occurs when women have been slapped, pushed, hit, kicked, dragged, beaten, chocked, burnt, threatened or assaulted by the partner (or ex-partner) with a weapon, knife or other object that can hurt. Finally, sexual domestic violence describes a situation where women have experienced a forced sexual intercourse, sexual coercion or sexual abuse, and this has been perpetrated by their partners (or ex-partners). ${ }^{16}$

According to our data, $11.6 \%$ of women reported experiencing emotional violence in the last 12 months; $5.2 \%$ reported experiencing physical violence; and $2.3 \%$ reported experiencing sexual violence. There are several reasons to expect a relationship between exposure to domestic violence and the outcomes under analysis in this paper. In general, women who suffer from domestic violence may be less able to control their fertility and contraceptive use. Moreover, since Zika can be sexually transmitted, women who report having suffered from sexual domestic violence in the last 12 months are expected to have a higher likelihood of having been diagnosed with Zika in the last 12 months.

\section{[Insert Table 6 about here] \\ [Insert Table 7 about here] \\ [Insert Table 8 about here]}

\footnotetext{
${ }^{16}$ See Carvalho and Oliveira (2016) for more details. The questions used to collect information on domestic violence were based on Maria da Penha Law and on WHO Multi-Country Study on Women's Health and Domestic Violence Against Women (WHO, 2005).
} 
In Table 6 we find that women who experienced sexual domestic violence in the last 12 months were more likely to report to have been diagnosed with Zika in the last 12 months $(\mathrm{OR}=1.80$, p-value $<0.01)$ and to have suffered from Zika symptoms $(\mathrm{OR}=1.42$, $\mathrm{p}$-value $<0.1)$. Suffering from other types of domestic violence did not appear to be related with our Zika incidence measures. These findings are consistent with (at least some) Zika (cases) being sexually transmitted.

Table 7 shows that women who experienced sexual domestic violence in the last 12 months were more likely to have used mosquito repellent or insecticides in the last 12 months $(\mathrm{OR}=1.66$, p-value<0.05). However, given the results of the joint significance tests on the domestic violence variables, we cannot reject that domestic violence was unrelated to Zika preventive behaviors.

In Table 8 we find that experiencing sexual domestic violence in the last 12 months was negatively related with reported knowledge that Zika is associated with malformation in newborns $(\mathrm{OR}=0.49, \mathrm{p}$-value $<0.1)$. Domestic violence in the last 12 months was unrelated to being currently pregnant $\left(\chi^{2}(3)=3.42\right.$, p-value $\left.=0.3310\right)$. Finally, women who suffered from emotional domestic violence in the last 12 months were more likely to report contraceptive behavior $(\mathrm{OR}=1.23$, $\mathrm{p}$-value $<0.05)$. Once again, however, given the results of the joint significance tests on the domestic violence variables, we cannot reject that domestic violence was unrelated to reproductive behaviors.

When analyzing the role of domestic violence, we are effectively performing 36 hypotheses tests ( 3 variables of domestic violence times 12 different outcomes). If these hypotheses tests were independent, we would expect that about 2 (4) out of 36 will be statistically significant at the 5\% (10\%) significance level. In other words, the two findings that are significant at the $5 \%$ and $10 \%$ level respectively do not survive a 
standard (Bonferroni) adjustment for multiple testing. ${ }^{17}$ Given this, perhaps the main message from the analysis of this subsection is that a few Zika cases can be explained by sexual domestic violence, which is consistent with a sexual transmission mechanism. A back-of-the-envelope calculation suggests that $1 \%$ of the cases of Zika (in the last 12 months) among women aged 15-49 may be explained by sexual domestic violence (in the last 12 months). ${ }^{18}$

\section{DISCUSSION}

In this section we discuss our findings in light of the existing estimates. Official statistics from the Epidemiological Reports of the Ministry of Health show that the incidence rate of Zika in the whole Northeast region jumped from 53.5 per 100,000 inhabitants in the $13^{\text {th }}$ epidemiological week to 134.4 per 100,000 inhabitants in the $52^{\text {nd }}$ epidemiological week of 2016. Approximately $60 \%$ of the total number of reported cases of Zika up to the $52^{\text {nd }}$ epidemiological week were confirmed, while the rest of notifications were discarded or were still under investigation. This indicates that such (official) incidence rate may provide an underestimate of the actual incidence rate.

Another reason to believe that the Zika incidence rate based on surveillance data is underestimated is that notifications of Zika reported to health authorities are based on a self-selected population, individuals who search for health services. If individuals who search for health services are those exhibiting strong symptoms of the disease, the incidence based on surveillance data may reflect (only) the most serious cases of Zika.

\footnotetext{
17 The Bonferroni correction rejects the null hypothesis for each p-value $<\alpha / m$, where $\alpha$ is the significance level and $m$ is the total number of null hypotheses.

${ }^{18}$ The number of self-reported diagnosed Zika cases is $0.23 * 10094=2321.62$. The number of Zika cases explained by sexual domestic violence is $0.1 * 0.023 * 10094=23.2162$. Hence, $23.2162 / 2321.62=0.01$. See Table B5 in the online appendix.
} 
Figure 1 displays the official incidence rate of Zika according to the $52^{\text {nd }}$ epidemiological report of the Ministry of Health in 2016 and the estimated incidence of

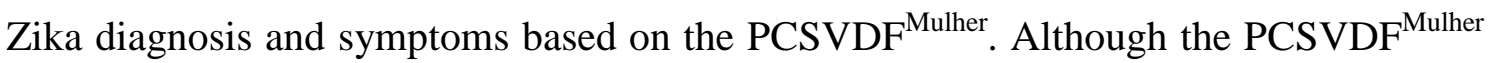
is restricted to women aged 15-49 in the nine Northeastern capitals, our estimated incidence rates $(\%)$ are much larger than the official incidence rates reported by the Ministry of Health (per 100,000 inhabitants). The correlation between the incidence rate and Zika diagnosis is 0.637 ( $\mathrm{p}$-value $=0.0650)$, whereas the correlation between the incidence rate and Zika symptoms is $0.563(\mathrm{p}$-value $=0.1146) .{ }^{19}$

Zhang et al. (2017) analyzed the spread of Zika in the Americas and estimated Zika infection rates, defined as the ratio between the cumulative number of new infections, both symptomatic and asymptomatic, during the period of analysis and the total population of a given region. Their estimated infection rate in Brazil was $16 \%$ on February 1, 2016, when the WHO declared Zika a Public Health Emergency of International Concern. This is the estimated infection rate for Brazil right before survey teams of the PCSVDF ${ }^{\text {Mulher }}$ began the field work. About one year later, February 28, 2017, the estimated infection rate in Brazil remained statistically the same, $18 \%$. In the state of Bahia, their estimated infection rate was $31 \%(26-36,95 \% \mathrm{CI})$. In the PCSVDF $^{\text {Mulher }}$, the incidence rate of Zika diagnosis among women aged 15-49 was about $34.6 \%$ (31.8-37.4, 95\% CI), whereas that for Zika symptoms was 42\% (38.9-44.7, 95\% CI). Thus, the Zika incidence rates estimated with the PCSVDF ${ }^{\text {Mulher }}$ survey are in line with previous estimates.

\footnotetext{
${ }^{19}$ In some cases, there are large discrepancies between the official and the survey incidence rates. A few potential reasons for such discrepancies: (1) Incidence rate from health authorities are computed using notifications from the whole Northeastern states, whereas incidence rate based on the PCSVDF ${ }^{\text {Mulher }}$ are restricted to women aged 15 to 49 in the state capitals; (2) If private health providers do not report adequately their notifications about arboviruses (i.e., Dengue, Chikungunya, and Zika), most of the notifications investigated by health authorities are the ones reported by public health services; (3) Epidemiological bulletins report incidence rates using only confirmed cases.
} 
Diniz et al. (2017) report findings from a national survey in Brazil in June 2016 using mixed methods. They document that $56 \%$ of women reported that they had avoided (or tried to avoid) pregnancy because of the Zika epidemic. Our results are quite different. We document that $51 \%$ of women reported having used any contraceptive (or tried in any way) to delay or avoid getting pregnant in the last 12 months, and that among this $51 \%$, only $18 \%$ reported this behavior to be motivated by the Zika epidemic. The discrepancy between their findings and ours does not seem to be driven by the fact that we focus on the Northeast. If anything, the discrepancy is larger in the Northeast: Diniz et al. (2017) document that $66 \%$ of women reported trying to avoid pregnancy. Perhaps the discrepancy is driven by the different survey designs, including different wording of questions, and more importantly, different sampling procedures. While Diniz et al. (2017)'s sample is restricted to literate women aged 1839 in urban areas of Brazil, our sample is representative of urban areas of the Northeast. $^{20}$

\section{CONCLUSION}

This article provides new findings on Zika incidence, preventive and reproductive behaviors, and their correlates from a representative sample of women aged 15-49 in the capital cities of the nine states of the Northeast region of Brazil. We find that more educated women were less likely to report suffering from Zika (or its symptoms) and more likely to follow preventive measures against the Zika virus: having used long and light-colored clothes, having used mosquito repellent or insecticides, having used mosquito protective screens or kept windows closed, and having dumped standing water where mosquitoes can breed. In addition, more educated

\footnotetext{
${ }^{20}$ However, even if we restrict our sample to literate women aged 18-39, the estimated incidence of women trying to delay or avoid getting pregnant because of the Zika epidemic is $20 \%$.
} 
women were more likely to report being informed about the association between Zika and microcephaly and to avoid pregnancy in the last 12 months. Finally, we also find that women who reported experiencing sexual domestic violence in the last 12 months were more likely to report suffering from Zika.

Our study can effectively contribute to guide the Family Health Program, which provides primary health care services at the community level, by identifying sociodemographic groups who are most exposed and vulnerable to the Zika epidemic, and their main preventive and reproductive behavioral responses. One of these responses is the postponement of pregnancy, which suggests a potential increase in the demand for family planning advice in the primary health care service and contraceptives.

In addition, our study can contribute to the public policy of endemic disease control, since we also investigate the correlates of the likelihood of visits by endemic disease control agents. The control of Aedes aegypti has been intensified since the declaration of public health emergency by the Ministry of Health at the end of 2015, including the mobilization of armed forces to survey households (Augusto et al., 2016). However, the vector control program has not prevented the spread and introduction of diseases transmitted by the Aedes aegypti, not even in areas with a well-organized public health system (Castro, 2016). 


\section{REFERENCES}

Augusto, L. G. S., Gurgel, A. M., Costa, A. M., Diderichsen, F., Lacaz, F.A., Parra-Henao, G., Riggoto, R. M., Nodari, R., Santos, S. L., 2016. Aedes aegypti control in Brazil. The Lancet, 387, 1052-1053.

de Araújo, T.V.B., Rodrigues, L. C., Ximenes, R. A. A., et al., 2016. Association between Zika virus infection and microcephaly in Brazil, January to May, 2016: preliminary report of a case-control study. Lancet Infectious Diseases. 16 (12), 13561363.

Calvet, G., Aguiar, R.S., Melo, A.S., et al., 2016. Detection and sequencing of Zika virus from amniotic fluid of fetuses with microcephaly in Brazil: a case study. Lancet Infectious Diseases. 16 (6), 653-660.

Carvalho, J.R. and Oliveira, V.H. 2016. Pesquisa de Condições Socioeconômicas e Violência Doméstica e Familiar contra a Mulher: Prevalência da Violência Doméstica e Impacto nas Novas Gerações. Relatório Executivo I. Fortaleza, Universidade Federal do Ceará.

Castro, M. 2016. Zika virus and health system in Brazil: from unknown to a menace. Health System \& Reform, 2(2), 119-122.

Chiaravalloti Neto, F., Barbosa, A. A., Cesarino, M. B., Favaro, E. A., Mondini, A., Ferraz, A. A., Dibo, M. R., Vicentini, M. E., 2006. Dengue control in an urban area of Brazil: impact of the Family Health Program on traditional control. Cad Saúde Pública, 22(5), 987-997.

Campos G.S., Bandeira, A.C., Sardi, S.I., 2015. Zika virus outbreak, Bahia, Brazil. Emerging Infectious Diseases. 21 (10), 1885-1886. 
Diniz, D., Madeiros, M, and Madeiro, A., 2017. Brazilian women avoiding pregnancy during Zika epidemic. Journal of Family Planning and Reproductive Health Care. $43(1), 80$.

Faria N. R., Azevedo R., Kraemer M. U., Souza R., Cunha M. S., Hill S. C., et al, 2016. Zika virus in the Americas: early epidemiological and genetic findings. Science, 352(6283), 345-349

Faria N. R., Quick J., Calro I. M., de Jesus, J. G., Giovanetti, M., Kraemer, S. et al, 2017. Establishment and cryptic transmission of Zika vírus in Brazil and the Americas. Nature, 546, 406-410.

Fauci, A.S., Morens, D.M., 2016. Zika virus in the Americas - yet another arbovirus threat. New England Journal of Medicine. 374, 601-604.

Foy, B.D., Kobylinski, K.C., Chilson, Foy J.L., et al., 2016. Probable nonvector-borne transmission of Zika virus, Colorado, USA. Emerging Infectious Diseases. $17,880-882$.

Galama, T., Lleras-Muney, A., and Kippersluis, H. 2018. The Effect of Education on Health and Mortality: A Review of Experimental and Quasi-Experimental Evidence. Oxford Research Encyclopedia of Economics and Finance, forthcoming

Jouannic, J.M., Friszer, S., Leparc-Goffart, I., Garel, C., Eyrolle-Guignot, D., 2016. Zika virus infection in French Polynesia. Lancet. 387 (10023), 1051-1052.

Kindhauser M.K., Allen T., Frank V., Santhana R. S., Dye C., 2016. Zika: the origin and spread of a mosquito-borne virus. Bull World Health Organ, 94:675-686C.

MMWR, 2016a. Transmission of Zika virus through sexual contact with travelers to areas of ongoing transmission — continental United States, 2016. Morbidity and Mortality Weekly Report. 65, 215-216. 
MMWR, 2016b. Zika virus infection among U.S. pregnant travelers — August 2015-February 2016. Morbidity and Mortality Weekly Report. 65, 211-214.

O liveira Melo, A.S., Malinger, G., Ximenes, R., Szejnfeld, P.O., Alves Sampaio, S., Bispo de Filippis, A.M., 2016. Zika virus intrauterine infection causes fetal brain abnormality and microcephaly: tip of the iceberg? Ultrasound in Obstetrics \& Gynecology. 47, 6-7.

Petersen L.R., Jamieson, D.J., Powers, A.M., Honein M.A., 2016. Zika virus. New England Journal of Medicine. 374 (16), 1552-1563.

Possas C., 2016. Zika: what we do and do not know based on the experiences of Brazil. Epidemiol Health, 38, e2016023.

Rasmussen S.A., Jamieson D.J., Honein M.A., Petersen, L.R., 2016. Zika Virus and Birth Defects - Reviewing the evidence for causality. New England Journal of Medicine. 374 (20), 1981-1987.

Rhee M, Sissoko M, Perry S, McFarland W, Parsonnet J, Doumbo O (2005). Use of insecticide-treated nets (ITNs) following a malaria education intervention in Piron, Mali: a control trial with systematic allocation of households. Malaria Journal, $4: 35$.

van der Linden, V., Pessoa, A., Dobyns, W., et al., 2016. Description of 13 infants born during October 2015-January 2016 with congenital Zika virus infection without microcephaly at birth — Brazil. MMWR Morbidity and Mortality Weekly Report. 65(47), 1343-1348.

Venturi, G., Zammarchi, L., Fortuna, C., et al., 2016. An autochthonous case of Zika due to possible sexual transmission, Florence, Italy, 2014. Eurosurveillance. 21 (8). 
WHO, 2005. Multi-country study on women's health and domestic violence against women: REPORT - Initial results on prevalence, health outcomes and women's responses. Geneva, World Health Organization.

WHO, 2015. Zika virus outbreak in the Americas. World Health Organization. Weekly Epidemiological Records. 45(6), 609-616.

Worobey M., 2017. Epidemiology: molecular mapping of Zika spread. Nature, $546,355-357$.

Zanluca, C., Andrade de Melo, V.C., Mosimann, A.L.P, et al., 2015. First report of autochthonous transmission of Zika virus in Brazil. Memórias do Instituto Oswaldo Cruz. 110, 569-72.

Zhang Q., Sun K., Chinazzi M., Pastore y Piontti A., Dean N. E., Rojas D. P., Merler S., Mistry D., Poletti P., Rossi L., Bray M., Halloran M. E., Longini Jr. I. M., Vespignani A., 2017. Spread of Zika virus in the Americas. PNAS, 114 (22), E4334E4343. 
Figure 1: Incidence rate of Zika disease (Ministry of Health) and Zika diagnosis/symptoms (PCSVDF ${ }^{\text {Mulher }}$ )

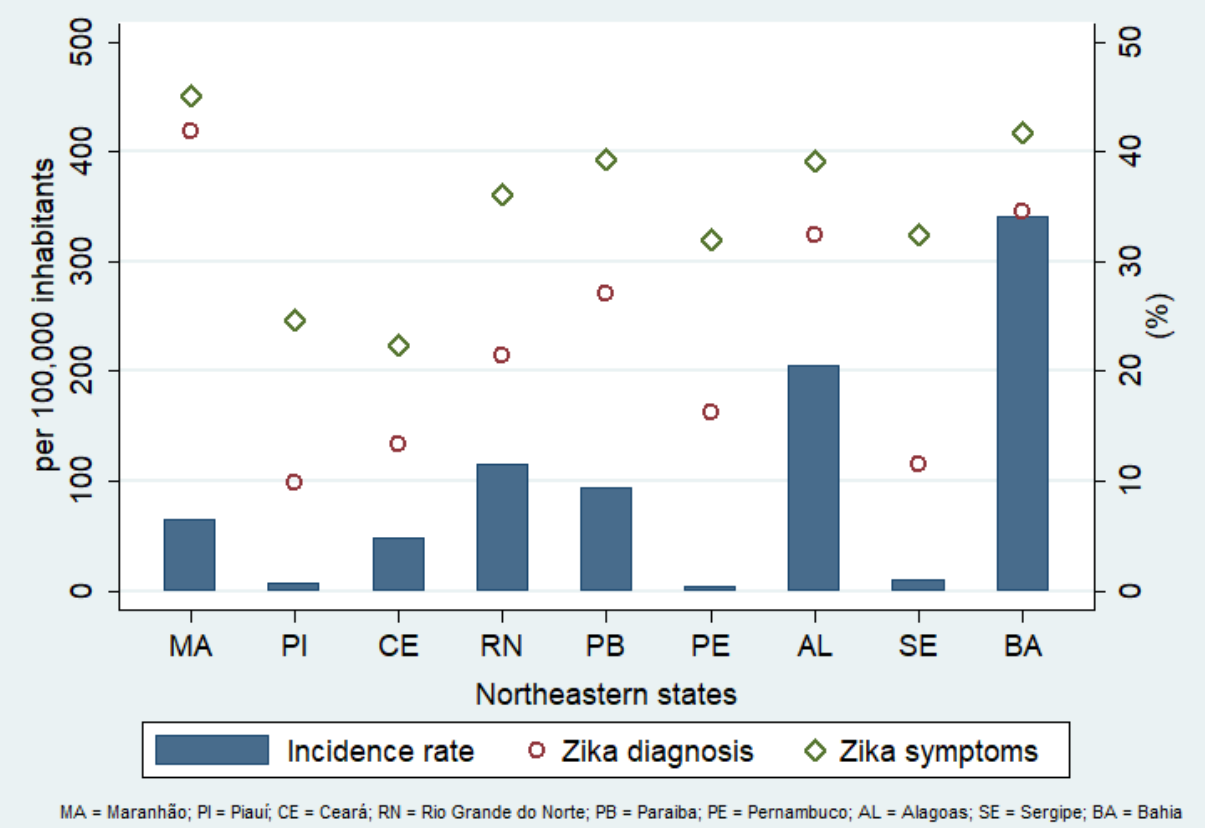

Source: Own elaboration using PCSVDF ${ }^{\text {Mulher }}$ and Epidemiological Reports/Ministry of Health. 


\begin{tabular}{|c|c|c|c|c|}
\hline & \multicolumn{2}{|c|}{ PCSVDF $^{\text {Mulher }}$} & \multicolumn{2}{|c|}{ PNADC/IBGE } \\
\hline & $\mathbf{N}$ & $\%$ & $\mathbf{N}$ & $\%$ \\
\hline \multicolumn{5}{|l|}{ Age } \\
\hline $15-19$ & 1,269 & 12.57 & 1,577 & 14.35 \\
\hline $20-24$ & 1,521 & 15.07 & 1,581 & 14.39 \\
\hline $25-29$ & 1,574 & 15.59 & 1,579 & 14.37 \\
\hline $30-34$ & 1,530 & 15.16 & 1,674 & 15.23 \\
\hline $35-39$ & 1,423 & 14.10 & 1,626 & 14.80 \\
\hline $40-45$ & 1,261 & 12.49 & 1,541 & 14.02 \\
\hline $45-49$ & 1,516 & 15.02 & 1,410 & 12.83 \\
\hline \multicolumn{5}{|l|}{ Education } \\
\hline No education & 101 & 1.00 & 443 & 4.03 \\
\hline Some fundamental school & 1,638 & 16.23 & 1,671 & 15.21 \\
\hline Fundamental school & 674 & 6.68 & 1,060 & 9.65 \\
\hline Some high school & 1,536 & 15.22 & 1,086 & 9.88 \\
\hline High school or technical formation & 4,100 & 40.62 & 4,107 & 37.38 \\
\hline Some college & 990 & 9.81 & 906 & 8.25 \\
\hline College or graduate studies & 1,034 & 10.24 & 1,715 & 15.61 \\
\hline Missing & 21 & 0.21 & - & - \\
\hline \multicolumn{5}{|l|}{ Self-reported Race/Color } \\
\hline White & 2,414 & 23.92 & 2,818 & 25.65 \\
\hline Black & 2,270 & 22.49 & 1,216 & 11.07 \\
\hline Brown & 5,268 & 52.19 & 6,898 & 62.78 \\
\hline Asian & 8 & 0.08 & 30 & 0.27 \\
\hline Indigenous & 41 & 0.41 & 26 & 0.24 \\
\hline Missing & 93 & 0.92 & - & - \\
\hline Observations & 10,094 & & 10,988 & \\
\hline
\end{tabular}

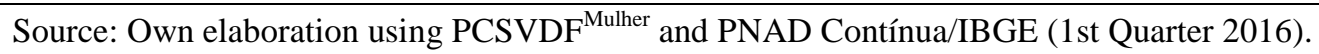


Table 2: Stylized facts.

Mean (\%) $\quad 95 \% \mathrm{CI}$

A. Incidence of Zika and symptoms

In the past 12 months, have you been diagnosed with Zika?

$22.46-24.13$

In the past 12 months, have you had mild fever, rash, and/or joint pain?

34.80

$33.86-35.74$

In the past 12 months, has there been any Zika case in your household?

48.59

$47.60-49.58$

In the past 12 months, have you heard/known about any

Zika case in your neighborhood?

$67.20 \quad 66.25-68.14$

In the past 12 months, have you received the visit of endemic diseases (dengue, Zika, etc.) control agents?

59.30

$58.31-60.27$

B. Preventive behaviors

In the past 12 months, have you used long and lightcolored clothes, even during hot days?

In the past 12 months, have you used mosquito repellent or insecticides?

$19.97-21.58$

In the past 12 months, have you used mosquito

protective screens or kept windows closed?

$13.28-14.66$

In the past 12 months, have you dumped standing water where mosquitos can breed?

78.61

$77.78-79.41$

C. Reproductive behaviors

Did you know that Zika is associated with malformation in newborns (microcephaly)?

Are you pregnant now?

96.12

$95.73-96.50$

In the past 12 months, have you used any contraceptive (or tried in any way) to delay or avoid getting pregnant?

$3.87-4.74$

If yes, is it because the Zika virus epidemic?

50.88

$49.81-51.95$

Source: Own elaboration using PCSVDF ${ }^{\text {Mulher }}$. 95\% CI: binomial exact $95 \%$ confidence interval. 


\begin{tabular}{|c|c|c|c|c|c|}
\hline & $\begin{array}{l}\text { Diagnosed } \\
\text { with Zika }\end{array}$ & $\begin{array}{c}\text { Zika } \\
\text { symptoms }\end{array}$ & $\begin{array}{l}\text { Zika in the } \\
\text { household }\end{array}$ & $\begin{array}{l}\text { Zika in the } \\
\text { neighborhood }\end{array}$ & $\begin{array}{c}\text { Home visit } \\
\text { from EDC } \\
\text { agent }\end{array}$ \\
\hline $20-24$ & $\begin{array}{c}1.475 * * * \\
(0.148)\end{array}$ & $\begin{array}{l}1.246^{* * *} \\
(0.107)\end{array}$ & $\begin{array}{l}0.873^{*} \\
(0.071)\end{array}$ & $\begin{array}{c}0.903 \\
(0.082)\end{array}$ & $\begin{array}{c}1.098 \\
(0.090)\end{array}$ \\
\hline $25-29$ & $\begin{array}{c}1.490 * * * \\
(0.149)\end{array}$ & $\begin{array}{l}1.234^{* *} \\
(0.106)\end{array}$ & $\begin{array}{l}0.866^{*} \\
(0.071)\end{array}$ & $\begin{array}{c}1.063 \\
(0.097)\end{array}$ & $\begin{array}{c}1.257 * * * \\
(0.103)\end{array}$ \\
\hline $30-34$ & $\begin{array}{c}1.355 * * * \\
(0.137)\end{array}$ & $\begin{array}{c}1.242^{* *} \\
(0.107)\end{array}$ & $\begin{array}{c}0.921 \\
(0.075)\end{array}$ & $\begin{array}{l}1.010 \\
(0.092)\end{array}$ & $\begin{array}{l}1.202 * * \\
(0.099)\end{array}$ \\
\hline $35-39$ & $\begin{array}{c}1.535 * * * \\
(0.155)\end{array}$ & $\begin{array}{c}1.523 * * * \\
(0.131)\end{array}$ & $\begin{array}{c}0.885 \\
(0.073)\end{array}$ & $\begin{array}{c}1.084 \\
(0.101)\end{array}$ & $\begin{array}{c}1.261^{* * * *} \\
(0.105)\end{array}$ \\
\hline $40-45$ & $\begin{array}{c}1.604 * * * \\
(0.166)\end{array}$ & $\begin{array}{c}1.570 * * * \\
(0.139)\end{array}$ & $\begin{array}{c}0.920 \\
(0.078)\end{array}$ & $\begin{array}{c}1.029 \\
(0.098)\end{array}$ & $\begin{array}{c}1.318 * * * \\
(0.114)\end{array}$ \\
\hline $45-49$ & $\begin{array}{c}1.589 * * * \\
(0.158)\end{array}$ & $\begin{array}{c}1.647 * * * \\
(0.139)\end{array}$ & $\begin{array}{l}0.870^{*} \\
(0.071)\end{array}$ & $\begin{array}{c}1.079 \\
(0.099)\end{array}$ & $\begin{array}{c}1.472 * * * \\
(0.122)\end{array}$ \\
\hline Black & $\begin{array}{c}1.046 \\
(0.080)\end{array}$ & $\begin{array}{c}1.059 \\
(0.070)\end{array}$ & $\begin{array}{c}1.056 \\
(0.068)\end{array}$ & $\begin{array}{c}1.093 \\
(0.079)\end{array}$ & $\begin{array}{l}1.165^{* *} \\
(0.076)\end{array}$ \\
\hline Brown & $\begin{array}{c}1.096 \\
(0.069)\end{array}$ & $\begin{array}{l}1.110^{*} \\
(0.060)\end{array}$ & $\begin{array}{l}1.123 * * \\
(0.058)\end{array}$ & $\begin{array}{c}1.093 \\
(0.064)\end{array}$ & $\begin{array}{c}1.203 * * * \\
(0.063)\end{array}$ \\
\hline Asian/Indigenous & $\begin{array}{c}0.849 \\
(0.326)\end{array}$ & $\begin{array}{c}0.901 \\
(0.286)\end{array}$ & $\begin{array}{c}1.069 \\
(0.319)\end{array}$ & $\begin{array}{c}0.750 \\
(0.238)\end{array}$ & $\begin{array}{c}0.935 \\
(0.280)\end{array}$ \\
\hline Fundamental school & $\begin{array}{c}0.937 \\
(0.075)\end{array}$ & $\begin{array}{c}0.924 \\
(0.065)\end{array}$ & $\begin{array}{c}1.026 \\
(0.071)\end{array}$ & $\begin{array}{c}0.945 \\
(0.072)\end{array}$ & $\begin{array}{c}1.063 \\
(0.074)\end{array}$ \\
\hline High school education & $\begin{array}{c}0.783 * * * \\
(0.055)\end{array}$ & $\begin{array}{c}0.817 * * * \\
(0.050)\end{array}$ & $\begin{array}{c}0.975 \\
(0.059)\end{array}$ & $\begin{array}{c}0.984 \\
(0.066)\end{array}$ & $\begin{array}{c}1.235 * * * \\
(0.075)\end{array}$ \\
\hline College education & $\begin{array}{c}0.542 * * * \\
(0.057)\end{array}$ & $\begin{array}{c}0.519 * * * \\
(0.047)\end{array}$ & $\begin{array}{c}0.824 * * \\
(0.070)\end{array}$ & $\begin{array}{c}0.856 \\
(0.081)\end{array}$ & $\begin{array}{c}1.139 \\
(0.098)\end{array}$ \\
\hline Aracaju & $\begin{array}{c}1.157 \\
(0.171)\end{array}$ & $\begin{array}{c}1.457 * * * \\
(0.148)\end{array}$ & $\begin{array}{l}1.188^{*} \\
(0.118)\end{array}$ & $\begin{array}{c}1.459 * * * \\
(0.137)\end{array}$ & $\begin{array}{c}0.712 * * * \\
(0.072)\end{array}$ \\
\hline Fortaleza & $\begin{array}{l}1.403 * * \\
(0.194)\end{array}$ & $\begin{array}{c}0.885 \\
(0.091)\end{array}$ & $\begin{array}{c}1.527 * * * \\
(0.143)\end{array}$ & $\begin{array}{c}1.565^{* * * *} \\
(0.141)\end{array}$ & $\begin{array}{c}0.510^{* * * *} \\
(0.049)\end{array}$ \\
\hline João Pessoa & $\begin{array}{c}3.489 * * * \\
(0.449)\end{array}$ & $\begin{array}{c}2.062 * * * \\
(0.203)\end{array}$ & $\begin{array}{c}2.648 * * * \\
(0.250)\end{array}$ & $\begin{array}{c}6.130 * * * \\
(0.622)\end{array}$ & $\begin{array}{c}0.307 * * * \\
(0.030)\end{array}$ \\
\hline Maceió & $\begin{array}{c}4.431 * * * \\
(0.568)\end{array}$ & $\begin{array}{c}2.033 * * * \\
(0.203)\end{array}$ & $\begin{array}{c}4.076 * * * \\
(0.395)\end{array}$ & $\begin{array}{c}9.407 * * * \\
(1.047)\end{array}$ & $\begin{array}{c}0.204 * * * \\
(0.020)\end{array}$ \\
\hline Natal & $\begin{array}{c}2.539 * * * \\
(0.338)\end{array}$ & $\begin{array}{c}1.797 * * * \\
(0.180)\end{array}$ & $\begin{array}{c}2.633 * * * \\
(0.252)\end{array}$ & $\begin{array}{c}5.381 * * * \\
(0.546)\end{array}$ & $\begin{array}{c}0.410 * * * \\
(0.040)\end{array}$ \\
\hline Recife & $\begin{array}{c}1.790 * * * \\
(0.238)\end{array}$ & $\begin{array}{c}1.489 * * * \\
(0.144)\end{array}$ & $\begin{array}{c}2.076 * * * \\
(0.190)\end{array}$ & $\begin{array}{c}4.118 * * * \\
(0.381)\end{array}$ & $\begin{array}{c}0.504 * * * \\
(0.048)\end{array}$ \\
\hline Salvador & $\begin{array}{c}4.876 * * * \\
(0.618)\end{array}$ & $\begin{array}{c}2.223 * * * \\
(0.218)\end{array}$ & $\begin{array}{c}4.129 * * * \\
(0.395)\end{array}$ & $\begin{array}{c}5.011 * * * \\
(0.495)\end{array}$ & $\begin{array}{c}0.688 * * * \\
(0.068)\end{array}$ \\
\hline São Luís & $\begin{array}{c}7.064 * * * \\
(0.882) \\
\end{array}$ & $\begin{array}{c}2.726 * * * \\
(0.264) \\
\end{array}$ & $\begin{array}{c}5.276 * * * \\
(0.508) \\
\end{array}$ & $\begin{array}{c}10.987 * * * \\
(1.224) \\
\end{array}$ & $\begin{array}{c}0.751 * * * \\
(0.075) \\
\end{array}$ \\
\hline $\begin{array}{l}\text { Joint significance test } \\
\text { Education variables } \chi^{2}(3)\end{array}$ & $40.15 * * *$ & $57.11 * * *$ & $7.54 *$ & 3.46 & $15.16 * * *$ \\
\hline $\begin{array}{l}\text { Log Likelihood } \\
\text { Observations }\end{array}$ & $\begin{array}{c}-4948.105 \\
9765\end{array}$ & $\begin{array}{c}-6167.453 \\
9820\end{array}$ & $\begin{array}{c}-6449.202 \\
9797\end{array}$ & $\begin{array}{c}-5386.496 \\
9483\end{array}$ & $\begin{array}{c}-6272.804 \\
9686\end{array}$ \\
\hline
\end{tabular}

Exponentiated coefficients. Standard errors in parentheses.

$* \mathrm{p}<0.10 . * * \mathrm{p}<0.05, * * * \mathrm{p}<0.01$ 


\begin{tabular}{|c|c|c|c|c|}
\hline & $\begin{array}{l}\text { Long \& light- } \\
\text { colored clothes }\end{array}$ & $\begin{array}{l}\text { Mosquito repellent / } \\
\text { Insecticides }\end{array}$ & $\begin{array}{l}\text { Protective screens / } \\
\text { windows closed }\end{array}$ & $\begin{array}{c}\text { Dumped } \\
\text { standing water }\end{array}$ \\
\hline \multirow[t]{2}{*}{$20-24$} & 0.889 & $1.383 * * *$ & $1.377 * * *$ & 1.158 \\
\hline & $(0.123)$ & $(0.144)$ & $(0.161)$ & $(0.107)$ \\
\hline \multirow[t]{2}{*}{$25-29$} & $0.712^{* *}$ & $1.457 * * *$ & 1.155 & $1.287 * * *$ \\
\hline & $(0.102)$ & $(0.150)$ & $(0.137)$ & $(0.121)$ \\
\hline \multirow[t]{2}{*}{$30-34$} & 0.889 & $1.447 * * *$ & $1.304^{* *}$ & $1.430 * * *$ \\
\hline & $(0.123)$ & $(0.150)$ & $(0.154)$ & $(0.137)$ \\
\hline \multirow[t]{2}{*}{$35-39$} & 0.923 & $1.452 * * *$ & $1.226^{*}$ & $1.235^{* *}$ \\
\hline & $(0.129)$ & $(0.152)$ & $(0.147)$ & $(0.118)$ \\
\hline \multirow[t]{2}{*}{$40-45$} & 1.007 & 1.090 & 1.039 & $1.502 * * *$ \\
\hline & $(0.143)$ & $(0.123)$ & $(0.133)$ & $(0.151)$ \\
\hline \multirow[t]{2}{*}{$45-49$} & 0.894 & 1.165 & 1.073 & $1.486 * * *$ \\
\hline & $(0.125)$ & $(0.125)$ & $(0.130)$ & $(0.142)$ \\
\hline \multirow[t]{2}{*}{ Black } & 1.129 & 1.043 & 1.123 & 1.010 \\
\hline & $(0.120)$ & $(0.080)$ & $(0.100)$ & $(0.077)$ \\
\hline \multirow[t]{2}{*}{ Brown } & 0.948 & 0.985 & 1.012 & $1.186^{* * *}$ \\
\hline & $(0.085)$ & $(0.062)$ & $(0.074)$ & $(0.074)$ \\
\hline \multirow[t]{2}{*}{ Asian/Indigenous } & 0.640 & 0.938 & 1.168 & 1.291 \\
\hline & $(0.386)$ & $(0.330)$ & $(0.461)$ & $(0.487)$ \\
\hline \multirow[t]{2}{*}{ Fundamental school } & $1.378^{* *}$ & $1.431 * * *$ & 1.150 & $1.305 * * *$ \\
\hline & $(0.178)$ & $(0.135)$ & $(0.118)$ & $(0.103)$ \\
\hline \multirow[t]{2}{*}{ High school education } & $1.537 * * *$ & $1.897 * * *$ & $1.204 * *$ & $1.457 * * *$ \\
\hline & $(0.175)$ & $(0.156)$ & $(0.108)$ & $(0.100)$ \\
\hline \multirow[t]{2}{*}{ College education } & $2.300 * * *$ & $2.643 * * *$ & $1.583 * * *$ & $1.406 * * *$ \\
\hline & $(0.326)$ & $(0.275)$ & $(0.184)$ & $(0.143)$ \\
\hline \multirow[t]{2}{*}{ Aracaju } & 0.968 & $3.023 * * *$ & $1.601 * * *$ & 0.858 \\
\hline & $(0.164)$ & $(0.412)$ & $(0.239)$ & $(0.101)$ \\
\hline \multirow[t]{2}{*}{ Fortaleza } & $0.607 * * *$ & $1.480 * * *$ & 1.126 & $0.489 * * *$ \\
\hline & $(0.110)$ & $(0.213)$ & $(0.172)$ & $(0.052)$ \\
\hline \multirow[t]{2}{*}{ João Pessoa } & 0.890 & $2.246^{* * *}$ & $1.796 * * *$ & 0.959 \\
\hline & $(0.148)$ & $(0.308)$ & $(0.258)$ & $(0.112)$ \\
\hline \multirow[t]{2}{*}{ Maceió } & $1.586 * * *$ & $3.871 * * *$ & $2.918 * * *$ & $0.629 * * *$ \\
\hline & $(0.244)$ & $(0.516)$ & $(0.404)$ & $(0.071)$ \\
\hline \multirow[t]{2}{*}{ Natal } & $1.324 *$ & $2.626 * * *$ & $1.687 * * *$ & 1.117 \\
\hline & $(0.208)$ & $(0.359)$ & $(0.247)$ & $(0.135)$ \\
\hline \multirow[t]{2}{*}{ Recife } & $1.529 * * *$ & $4.042 * * *$ & $1.757 * * *$ & $0.784 * *$ \\
\hline & $(0.225)$ & $(0.520)$ & $(0.246)$ & $(0.086)$ \\
\hline \multirow[t]{2}{*}{ Salvador } & $1.390^{* *}$ & $3.252 * * *$ & $1.290 *$ & $0.627 * * *$ \\
\hline & $(0.214)$ & $(0.434)$ & $(0.193)$ & $(0.070)$ \\
\hline \multirow[t]{2}{*}{ São Luís } & $0.712^{* *}$ & $2.606 * * *$ & $2.343 * * *$ & $1.337 * *$ \\
\hline & $(0.122)$ & $(0.347)$ & $(0.323)$ & $(0.164)$ \\
\hline \multicolumn{5}{|l|}{ Joint significance test } \\
\hline Education variables $\chi^{2}(3)$ & $35.41 * * *$ & $103.01 * * *$ & $16.26 * * *$ & $30.45 * * *$ \\
\hline Log Likelihood & -2865.017 & -4799.740 & -3872.087 & -4932.329 \\
\hline Observations & 9738 & 9787 & 9771 & 9738 \\
\hline
\end{tabular}

Exponentiated coefficients. Standard errors in parentheses.

$* \mathrm{p}<0.10 . * * \mathrm{p}<0.05, * * * \mathrm{p}<0.01$ 


\begin{tabular}{|c|c|c|c|}
\hline & $\begin{array}{l}\text { Knows that Zika virus } \\
\text { may cause Microcephaly }\end{array}$ & $\begin{array}{l}\text { Currently } \\
\text { pregnant }\end{array}$ & $\begin{array}{l}\text { Currently using } \\
\text { contraceptive }\end{array}$ \\
\hline $20-24$ & $\begin{array}{c}1.261 \\
(0.235)\end{array}$ & $\begin{array}{c}1.208 \\
(0.242)\end{array}$ & $\begin{array}{c}1.077 \\
(0.111)\end{array}$ \\
\hline $25-29$ & $\begin{array}{c}1.715 * * * \\
(0.346)\end{array}$ & $\begin{array}{l}1.059 \\
(0.215)\end{array}$ & $\begin{array}{l}0.955 \\
(0.097)\end{array}$ \\
\hline $30-34$ & $\begin{array}{l}1.589 * * \\
(0.313)\end{array}$ & $\begin{array}{c}0.876 \\
(0.182)\end{array}$ & $\begin{array}{l}0.833^{*} \\
(0.084)\end{array}$ \\
\hline $35-39$ & $\begin{array}{c}1.233 \\
(0.232)\end{array}$ & $\begin{array}{c}0.383 * * * \\
(0.095)\end{array}$ & $\begin{array}{c}0.590 * * * \\
(0.060)\end{array}$ \\
\hline $40-45$ & $\begin{array}{l}1.575^{* * *} \\
(0.322)\end{array}$ & $\begin{array}{c}0.404 * * * \\
(0.102)\end{array}$ & $\begin{array}{c}0.374 * * * \\
(0.039)\end{array}$ \\
\hline $45-49$ & $\begin{array}{c}1.339 \\
(0.249)\end{array}$ & $\begin{array}{l}0.273 * * * \\
(0.073)\end{array}$ & $\begin{array}{c}0.205 * * * \\
(0.022)\end{array}$ \\
\hline Black & $\begin{array}{c}0.932 \\
(0.139)\end{array}$ & $\begin{array}{l}1.003 \\
(0.177)\end{array}$ & $\begin{array}{c}1.043 \\
(0.074)\end{array}$ \\
\hline Brown & $\begin{array}{c}1.556 * * * \\
(0.206)\end{array}$ & $\begin{array}{l}1.195 \\
(0.169)\end{array}$ & $\begin{array}{l}1.108^{*} \\
(0.064)\end{array}$ \\
\hline Asian/Indigenous & $\begin{array}{l}1.295 \\
(0.952)\end{array}$ & $\begin{array}{l}1.209 \\
(0.894)\end{array}$ & $\begin{array}{l}0.708 \\
(0.227)\end{array}$ \\
\hline Fundamental school & $\begin{array}{c}1.069 \\
(0.162)\end{array}$ & $\begin{array}{c}0.950 \\
(0.162)\end{array}$ & $\begin{array}{l}1.086 \\
(0.081)\end{array}$ \\
\hline High school education & $\begin{array}{c}1.663 * * * \\
(0.235)\end{array}$ & $\begin{array}{c}0.797 \\
(0.122)\end{array}$ & $\begin{array}{c}1.216 * * * \\
(0.079)\end{array}$ \\
\hline College education & $\begin{array}{c}1.650 * * \\
(0.373)\end{array}$ & $\begin{array}{c}0.712 \\
(0.163)\end{array}$ & $\begin{array}{c}1.366 * * * \\
(0.123)\end{array}$ \\
\hline Aracaju & $\begin{array}{l}0.629^{*} \\
(0.156)\end{array}$ & $\begin{array}{l}1.202 \\
(0.308)\end{array}$ & $\begin{array}{c}1.662 * * * \\
(0.175)\end{array}$ \\
\hline Fortaleza & $\begin{array}{c}0.590^{* *} \\
(0.141)\end{array}$ & $\begin{array}{c}1.322 \\
(0.316)\end{array}$ & $\begin{array}{c}1.329 * * * \\
(0.133)\end{array}$ \\
\hline João Pessoa & $\begin{array}{c}0.946 \\
(0.249)\end{array}$ & $\begin{array}{c}1.012 \\
(0.262)\end{array}$ & $\begin{array}{c}1.141 \\
(0.116)\end{array}$ \\
\hline Maceió & $\begin{array}{c}1.144 \\
(0.320)\end{array}$ & $\begin{array}{c}1.149 \\
(0.296)\end{array}$ & $\begin{array}{c}1.058 \\
(0.110)\end{array}$ \\
\hline Natal & $\begin{array}{l}1.201 \\
(0.337)\end{array}$ & $\begin{array}{l}1.479 \\
(0.366)\end{array}$ & $\begin{array}{c}1.606 * * * \\
(0.168)\end{array}$ \\
\hline Recife & $\begin{array}{c}0.523 * * * \\
(0.121)\end{array}$ & $\begin{array}{c}0.794 \\
(0.212)\end{array}$ & $\begin{array}{l}1.224 * * \\
(0.122)\end{array}$ \\
\hline Salvador & $\begin{array}{c}0.493 * * * \\
(0.116)\end{array}$ & $\begin{array}{l}1.373 \\
(0.337)\end{array}$ & $\begin{array}{c}1.690 * * * \\
(0.171)\end{array}$ \\
\hline São Luís & $\begin{array}{l}1.705^{*} \\
(0.527) \\
\end{array}$ & $\begin{array}{l}1.100 \\
(0.280) \\
\end{array}$ & $\begin{array}{c}0.866 \\
(0.087) \\
\end{array}$ \\
\hline $\begin{array}{l}\text { Joint significance test } \\
\text { Education variables } \chi^{2}(3)\end{array}$ & $18.52^{* * *}$ & 3.88 & $15.78 * * *$ \\
\hline $\begin{array}{l}\text { Log Likelihood } \\
\text { Observations }\end{array}$ & $\begin{array}{l}-1548.924 \\
9825\end{array}$ & $\begin{array}{c}-1440.519 \\
8434\end{array}$ & $\begin{array}{c}-5439.551 \\
8397\end{array}$ \\
\hline
\end{tabular}

Exponentiated coefficients. Standard errors in parentheses.

$* \mathrm{p}<0.10 . * * \mathrm{p}<0.05, * * * \mathrm{p}<0.01$ 


\begin{tabular}{|c|c|c|c|c|c|}
\hline & $\begin{array}{l}\text { Diagnosed } \\
\text { with Zika }\end{array}$ & $\begin{array}{c}\text { Zika } \\
\text { symptoms }\end{array}$ & $\begin{array}{l}\text { Zika in the } \\
\text { household }\end{array}$ & $\begin{array}{l}\text { Zika in the } \\
\text { neighborhood }\end{array}$ & $\begin{array}{l}\text { Home visit } \\
\text { from EDC } \\
\text { agent }\end{array}$ \\
\hline \multirow[t]{2}{*}{$20-24$} & $1.495 * * *$ & $1.240^{*}$ & $0.800^{*}$ & $0.756^{* *}$ & 1.100 \\
\hline & $(0.212)$ & $(0.150)$ & $(0.092)$ & $(0.099)$ & $(0.126)$ \\
\hline $25-29$ & $1.525 * * *$ & $1.264 * *$ & $0.806^{*}$ & 0.823 & $1.367^{* * *}$ \\
\hline $30-34$ & $\begin{array}{c}1.448 * * * \\
(0.205)\end{array}$ & $1.289^{* *}$ & 0.831 & $0.768 * *$ & 1.196 \\
\hline $35-39$ & $\begin{array}{l}1.405^{* *} \\
(0.203)\end{array}$ & $\begin{array}{c}1.546 * * * \\
(0.188)\end{array}$ & $\begin{array}{c}0.761 * * \\
(0.089)\end{array}$ & $\begin{array}{l}(0.100) \\
0.800^{*} \\
(0.107)\end{array}$ & $\begin{array}{l}(0.136) \\
1.341 * * \\
(0.157)\end{array}$ \\
\hline $40-45$ & $\begin{array}{c}1.447 * * \\
(0.212)\end{array}$ & $\begin{array}{c}1.564 * * * \\
(0.194)\end{array}$ & $\begin{array}{c}0.846 \\
(0.101)\end{array}$ & $\begin{array}{c}0.827 \\
(0.113)\end{array}$ & $\begin{array}{l}1.260^{*} \\
(0.151)\end{array}$ \\
\hline $45-49$ & $\begin{array}{c}1.642 * * * \\
(0.232)\end{array}$ & $\begin{array}{c}1.664 * * * \\
(0.199)\end{array}$ & $\begin{array}{c}0.858 \\
(0.099)\end{array}$ & $\begin{array}{c}0.885 \\
(0.117)\end{array}$ & $\begin{array}{c}1.511 * * * \\
(0.176)\end{array}$ \\
\hline Black & $\begin{array}{c}1.003 \\
(0.103)\end{array}$ & $\begin{array}{l}1.037 \\
(0.092)\end{array}$ & $\begin{array}{c}1.091 \\
(0.094)\end{array}$ & $\begin{array}{c}1.062 \\
(0.104)\end{array}$ & $\begin{array}{l}1.199 * * \\
(0.105)\end{array}$ \\
\hline Brown & $\begin{array}{l}1.110 \\
(0.096)\end{array}$ & $\begin{array}{c}1.123 \\
(0.083)\end{array}$ & $\begin{array}{l}1.167 * * \\
(0.083)\end{array}$ & $\begin{array}{c}1.009 \\
(0.081)\end{array}$ & $\begin{array}{l}1.197 * * \\
(0.085)\end{array}$ \\
\hline Asian/Indigenous & $\begin{array}{c}0.574 \\
(0.368)\end{array}$ & $\begin{array}{c}0.738 \\
(0.360)\end{array}$ & $\begin{array}{c}0.771 \\
(0.342)\end{array}$ & $\begin{array}{c}0.532 \\
(0.247)\end{array}$ & $\begin{array}{l}1.447 \\
(0.639)\end{array}$ \\
\hline Fundamental school & $\begin{array}{c}1.018 \\
(0.109)\end{array}$ & $\begin{array}{l}1.000 \\
(0.092)\end{array}$ & $\begin{array}{c}0.976 \\
(0.088)\end{array}$ & $\begin{array}{c}0.994 \\
(0.099)\end{array}$ & $\begin{array}{c}0.990 \\
(0.089)\end{array}$ \\
\hline High school education & $\begin{array}{c}0.910 \\
(0.084)\end{array}$ & $\begin{array}{c}0.906 \\
(0.072)\end{array}$ & $\begin{array}{c}0.949 \\
(0.074)\end{array}$ & $\begin{array}{l}1.138 \\
(0.098)\end{array}$ & $\begin{array}{c}1.287 * * * \\
(0.101)\end{array}$ \\
\hline College education or higher & $\begin{array}{c}0.566 * * * \\
(0.078)\end{array}$ & $\begin{array}{c}0.503 * * * \\
(0.060)\end{array}$ & $\begin{array}{c}0.771 * * \\
(0.085)\end{array}$ & $\begin{array}{c}0.903 \\
(0.112)\end{array}$ & $\begin{array}{c}1.181 \\
(0.132)\end{array}$ \\
\hline Emotional violence & $\begin{array}{c}0.816 \\
(0.104)\end{array}$ & $\begin{array}{c}1.011 \\
(0.107)\end{array}$ & $\begin{array}{l}1.058 \\
(0.108)\end{array}$ & $\begin{array}{c}1.162 \\
(0.137)\end{array}$ & $\begin{array}{c}0.880 \\
(0.091)\end{array}$ \\
\hline Physical violence & $\begin{array}{c}1.057 \\
(0.187)\end{array}$ & $\begin{array}{l}1.071 \\
(0.162)\end{array}$ & $\begin{array}{c}1.093 \\
(0.163)\end{array}$ & $\begin{array}{c}0.914 \\
(0.153)\end{array}$ & $\begin{array}{l}1.169 \\
(0.176)\end{array}$ \\
\hline Sexual violence & $\begin{array}{c}1.797 * * * \\
(0.401)\end{array}$ & $\begin{array}{l}1.415^{*} \\
(0.279)\end{array}$ & $\begin{array}{l}1.080 \\
(0.215)\end{array}$ & $\begin{array}{l}1.161 \\
(0.264)\end{array}$ & $\begin{array}{c}0.962 \\
(0.192)\end{array}$ \\
\hline Aracaju & $\begin{array}{c}1.075 \\
(0.226)\end{array}$ & $\begin{array}{l}1.357 * * \\
(0.190)\end{array}$ & $\begin{array}{c}1.174 \\
(0.157)\end{array}$ & $\begin{array}{c}1.062 \\
(0.136)\end{array}$ & $\begin{array}{c}0.864 \\
(0.120)\end{array}$ \\
\hline Fortaleza & $\begin{array}{l}1.429^{*} \\
(0.272)\end{array}$ & $\begin{array}{l}0.787^{*} \\
(0.109)\end{array}$ & $\begin{array}{c}1.228 \\
(0.154)\end{array}$ & $\begin{array}{c}1.115 \\
(0.134)\end{array}$ & $\begin{array}{c}0.564 * * * \\
(0.072)\end{array}$ \\
\hline João Pessoa & $\begin{array}{c}3.707 * * * \\
(0.660)\end{array}$ & $\begin{array}{c}2.072 * * * \\
(0.270)\end{array}$ & $\begin{array}{c}2.338^{* * * *} \\
(0.290)\end{array}$ & $\begin{array}{c}5.001 * * * \\
(0.654)\end{array}$ & $\begin{array}{c}0.330 * * * \\
(0.042)\end{array}$ \\
\hline Maceió & $\begin{array}{c}4.356 * * * \\
(0.786)\end{array}$ & $\begin{array}{c}1.735^{* * *} * \\
(0.236)\end{array}$ & $\begin{array}{c}3.444 * * * \\
(0.447)\end{array}$ & $\begin{array}{c}8.141^{* * *} \\
(1.214)\end{array}$ & $\begin{array}{c}0.219^{* * *} \\
(0.029)\end{array}$ \\
\hline Natal & $\begin{array}{c}2.341 * * * \\
(0.482)\end{array}$ & $\begin{array}{c}1.997 * * * \\
(0.299)\end{array}$ & $\begin{array}{c}2.388^{* * * *} \\
(0.342)\end{array}$ & $\begin{array}{c}3.782 * * * \\
(0.579)\end{array}$ & $\begin{array}{c}0.457 * * * \\
(0.067)\end{array}$ \\
\hline Recife & $\begin{array}{c}1.600^{* *} \\
(0.323)\end{array}$ & $\begin{array}{c}1.609 * * * \\
(0.227)\end{array}$ & $\begin{array}{c}1.575^{* * * *} \\
(0.211)\end{array}$ & $\begin{array}{c}3.044 * * * \\
(0.412)\end{array}$ & $\begin{array}{c}0.531 * * * \\
(0.073)\end{array}$ \\
\hline Salvador & $\begin{array}{c}4.909 * * * \\
(0.861)\end{array}$ & $\begin{array}{c}2.044 * * * \\
(0.264)\end{array}$ & $\begin{array}{c}3.990 * * * \\
(0.499)\end{array}$ & $\begin{array}{c}4.317 * * * \\
(0.550)\end{array}$ & $\begin{array}{c}0.759 * * \\
(0.098)\end{array}$ \\
\hline São Luís & $\begin{array}{c}8.103 * * * \\
(1.429)\end{array}$ & $\begin{array}{c}2.645 * * * \\
(0.350)\end{array}$ & $\begin{array}{c}5.139 * * * \\
(0.671)\end{array}$ & $\begin{array}{c}10.288^{* * * *} \\
(1.583)\end{array}$ & $\begin{array}{c}0.817 \\
(0.109)\end{array}$ \\
\hline \multicolumn{6}{|l|}{ Joint significance test } \\
\hline Education variables $\chi^{2}(3)$ & $21.03 * * *$ & $40.17 * * *$ & $6.26^{*}$ & $6.65^{*}$ & $17.49 * * *$ \\
\hline Domestic violence variables $\chi^{2}(3)$ & $8.39 * * *$ & 4.89 & 1.95 & 2.57 & 1.88 \\
\hline Log Likelihood & -2844.557 & -3560.329 & -3708.342 & -3056.543 & -3617.668 \\
\hline Observations & 5630 & 5670 & 5660 & 5457 & 5589 \\
\hline
\end{tabular}

Exponentiated coefficients. Standard errors in parentheses.

$* \mathrm{p}<0.10 . * * \mathrm{p}<0.05, * * * \mathrm{p}<0.01$ 


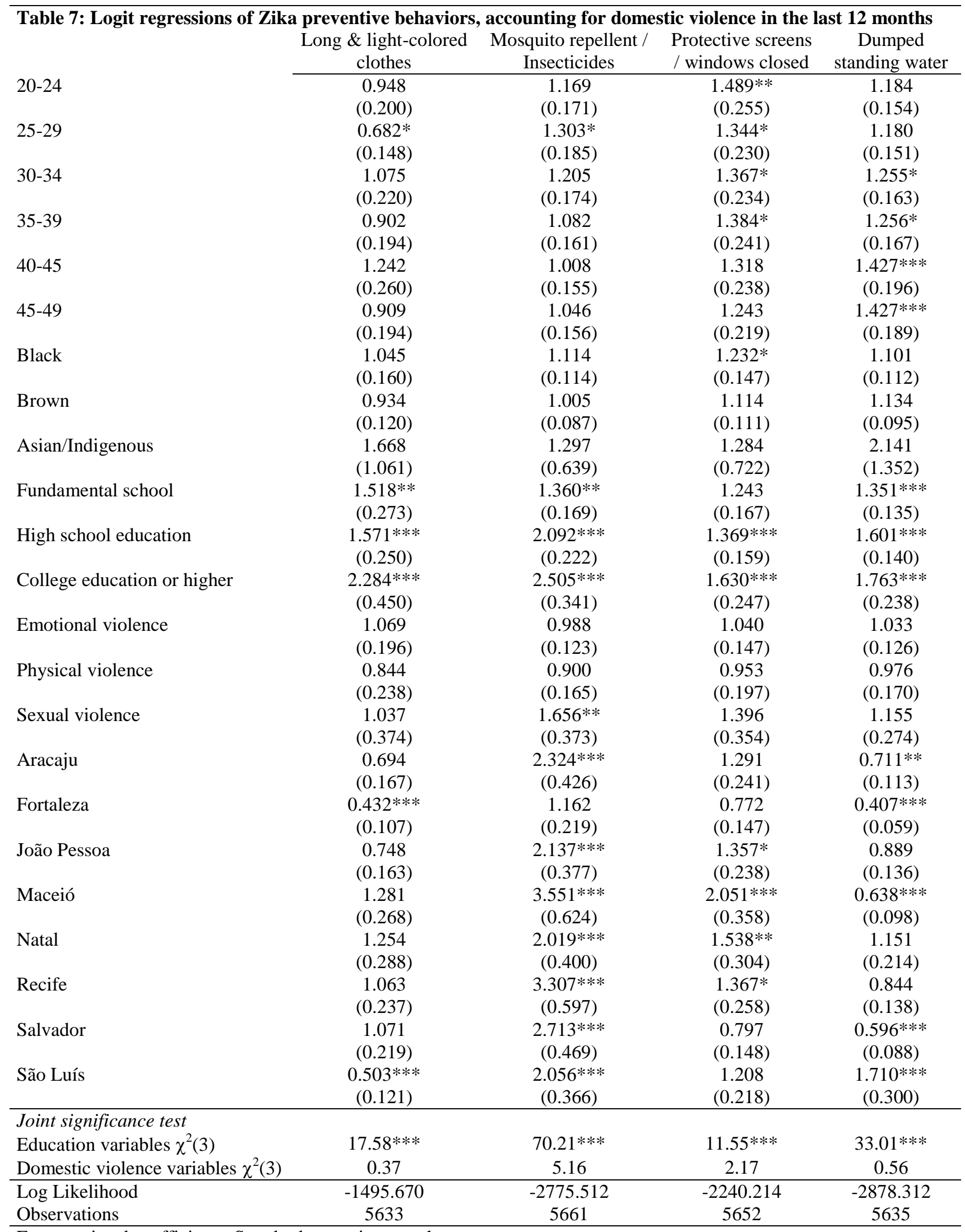

Exponentiated coefficients. Standard errors in parentheses.

$* \mathrm{p}<0.10 . * * \mathrm{p}<0.05, * * * \mathrm{p}<0.01$ 


\begin{tabular}{|c|c|c|c|}
\hline & $\begin{array}{l}\text { Knows that Zika virus } \\
\text { may cause Microcephaly }\end{array}$ & $\begin{array}{l}\text { Currently } \\
\text { pregnant }\end{array}$ & $\begin{array}{l}\text { Currently using } \\
\text { contraceptive }\end{array}$ \\
\hline $20-24$ & $\begin{array}{c}1.231 \\
(0.339)\end{array}$ & $\begin{array}{c}1.016 \\
(0.242)\end{array}$ & $\begin{array}{c}0.985 \\
(0.128)\end{array}$ \\
\hline $25-29$ & $\begin{array}{l}2.033 * * \\
(0.623)\end{array}$ & $\begin{array}{c}0.950 \\
(0.228)\end{array}$ & $\begin{array}{l}0.876 \\
(0.111)\end{array}$ \\
\hline $30-34$ & $\begin{array}{l}1.405 \\
(0.397)\end{array}$ & $\begin{array}{c}0.724 \\
(0.181)\end{array}$ & $\begin{array}{c}0.739 * * \\
(0.094)\end{array}$ \\
\hline $35-39$ & $\begin{array}{l}1.320 \\
(0.374)\end{array}$ & $\begin{array}{c}0.289 * * * \\
(0.092)\end{array}$ & $\begin{array}{c}0.519 * * * \\
(0.067)\end{array}$ \\
\hline $40-45$ & $\begin{array}{c}1.349 \\
(0.391)\end{array}$ & $\begin{array}{c}0.390 * * * \\
(0.117)\end{array}$ & $\begin{array}{c}0.306 * * * \\
(0.040)\end{array}$ \\
\hline $45-49$ & $\begin{array}{l}1.075 \\
(0.284)\end{array}$ & $\begin{array}{c}0.198 * * * \\
(0.069)\end{array}$ & $\begin{array}{c}0.181 * * * \\
(0.024)\end{array}$ \\
\hline Black & $\begin{array}{c}0.966 \\
(0.210)\end{array}$ & $\begin{array}{l}1.054 \\
(0.235)\end{array}$ & $\begin{array}{l}1.186^{*} \\
(0.106)\end{array}$ \\
\hline Brown & $\begin{array}{c}1.339 \\
(0.249)\end{array}$ & $\begin{array}{c}1.220 \\
(0.221)\end{array}$ & $\begin{array}{l}1.175^{* *} \\
(0.087)\end{array}$ \\
\hline Asian/Indigenous & $\begin{array}{c}0.915 \\
(0.956)\end{array}$ & $\begin{array}{c}1.121 \\
(1.169)\end{array}$ & $\begin{array}{l}0.646 \\
(0.286)\end{array}$ \\
\hline Fundamental school & $\begin{array}{c}1.254 \\
(0.251)\end{array}$ & $\begin{array}{c}0.941 \\
(0.194)\end{array}$ & $\begin{array}{c}1.100 \\
(0.103)\end{array}$ \\
\hline High school education & $\begin{array}{c}2.000 * * * \\
(0.373)\end{array}$ & $\begin{array}{c}0.748 \\
(0.140)\end{array}$ & $\begin{array}{c}1.349 * * * \\
(0.109)\end{array}$ \\
\hline College education or higher & $\begin{array}{c}2.081 * * \\
(0.664)\end{array}$ & $\begin{array}{c}0.658 \\
(0.190)\end{array}$ & $\begin{array}{c}1.523 * * * \\
(0.173)\end{array}$ \\
\hline Emotional violence & $\begin{array}{l}1.020 \\
(0.277)\end{array}$ & $\begin{array}{c}0.700 \\
(0.185)\end{array}$ & $\begin{array}{l}1.234 * * \\
(0.130)\end{array}$ \\
\hline Physical violence & $\begin{array}{c}1.018 \\
(0.377)\end{array}$ & $\begin{array}{c}1.058 \\
(0.391)\end{array}$ & $\begin{array}{c}0.859 \\
(0.131)\end{array}$ \\
\hline Sexual violence & $\begin{array}{l}0.485^{*} \\
(0.191)\end{array}$ & $\begin{array}{c}0.604 \\
(0.375)\end{array}$ & $\begin{array}{c}0.881 \\
(0.177)\end{array}$ \\
\hline Aracaju & $\begin{array}{l}0.589^{*} \\
(0.185)\end{array}$ & $\begin{array}{l}1.222 \\
(0.409)\end{array}$ & $\begin{array}{c}1.537 * * * \\
(0.209)\end{array}$ \\
\hline Fortaleza & $\begin{array}{l}0.685 \\
(0.211)\end{array}$ & $\begin{array}{l}1.447 \\
(0.440)\end{array}$ & $\begin{array}{c}0.945 \\
(0.119)\end{array}$ \\
\hline João Pessoa & $\begin{array}{l}1.055 \\
(0.347)\end{array}$ & $\begin{array}{c}1.156 \\
(0.371)\end{array}$ & $\begin{array}{l}0.967 \\
(0.123)\end{array}$ \\
\hline Maceió & $\begin{array}{l}1.529 \\
(0.572)\end{array}$ & $\begin{array}{c}1.043 \\
(0.356)\end{array}$ & $\begin{array}{l}0.785^{*} \\
(0.104)\end{array}$ \\
\hline Natal & $\begin{array}{l}1.470 \\
(0.627)\end{array}$ & $\begin{array}{c}1.694 \\
(0.579)\end{array}$ & $\begin{array}{l}1.410^{* *} \\
(0.213)\end{array}$ \\
\hline Recife & $\begin{array}{c}0.806 \\
(0.272)\end{array}$ & $\begin{array}{c}0.857 \\
(0.311)\end{array}$ & $\begin{array}{l}0.846 \\
(0.115)\end{array}$ \\
\hline Salvador & $\begin{array}{c}0.875 \\
(0.277)\end{array}$ & $\begin{array}{l}1.396 \\
(0.433)\end{array}$ & $\begin{array}{l}1.261^{*} \\
(0.159)\end{array}$ \\
\hline São Luís & $\begin{array}{l}3.340 * * \\
(1.621)\end{array}$ & $\begin{array}{c}1.200 \\
(0.391)\end{array}$ & $\begin{array}{l}0.802 * \\
(0.104)\end{array}$ \\
\hline $\begin{array}{l}\text { Joint significance test } \\
\text { Education variables } \chi^{2}(3)\end{array}$ & $16.16^{* * *}$ & 4.02 & $21.84 * * *$ \\
\hline Domestic violence variables $\chi^{2}(3)$ & 4.15 & 3.42 & 4.11 \\
\hline $\begin{array}{l}\text { Log Likelihood } \\
\text { Observations }\end{array}$ & $\begin{array}{l}-818.561 \\
5674\end{array}$ & $\begin{array}{l}-922.588 \\
5406\end{array}$ & $\begin{array}{l}-3457.325 \\
5392\end{array}$ \\
\hline
\end{tabular}

Exponentiated coefficients. Standard errors in parentheses.

$* \mathrm{p}<0.10 . * * \mathrm{p}<0.05, * * * \mathrm{p}<0.01$ 


\section{ONLINE APPENDIX (NOT FOR PUBLICATION)}

\section{A. ADDITIONAL INFORMATION ON THE PCSVDF ${ }^{\text {Mulher }}$ SURVEY}

\section{A.1. Sample design}

The sampling plan was drawn up by stratifying the population of households in three stages. In the first stage, census tracts were randomly selected from three groups that reflected the income distribution of each state capital visited by the PCSVDF ${ }^{\mathrm{Mulher}}$. These groups were based on the distribution of the average income of household heads at the level of census tracts. In the second stage, households were randomly selected from the previously selected census tracts. Finally, in the third stage, and to ensure the safety and confidentiality of respondents, only one woman aged 15-49 is randomly selected per household.

Table A1 reports the fraction of participants, refusals and not available respondents among eligible women. Figure A1 shows the geographical coverage of the PCSVDF ${ }^{\text {Mulher }}$ survey, and Table A2 compares the female population (PNADC, 2016) with the number of respondents (PCSVDF $\left.{ }^{\text {Mulher }}\right)$ by state capital.

The survey used carefully selected female interviewers and supervisors who attended a standardized three-week training course, covering issues of gender, violence, ethical and safety issues, as well as interview techniques. ${ }^{1}$ The WHO ethics guidelines required that all interviews take place in complete privacy except for infants younger than 2 years. Interviewers were trained in several strategies to ensure such privacy, including use of dummy questions in case someone entered the room, and use of decoy interviewers to ask questions of mothers-in-law or husbands if this was the only way to ensure privacy with the respondent. All interviews were conducted in the local language, and information about available local services was provided to all respondents.

\footnotetext{
${ }^{1}$ A 40-hour training at each one of the nine states was provided to roughly 25-35 interviewers per site (256 interviewers in total).
} 


\begin{tabular}{lcc}
\hline Table A1: Fraction of participants, refusals and not available & \\
\cline { 2 - 3 } & Frequency & $\%$ \\
Not in the household (NA) & 742 & 6.50 \\
Refused & 575 & 5.04 \\
Participants & 10,094 & 88.46 \\
\hline Total & 11,411 & 100 \\
\hline Source: Own elaboration using PCSVDF & &
\end{tabular}

\section{Figure A1: Geographical coverage of the PCSVDF ${ }^{\text {Mulher }}$ survey}

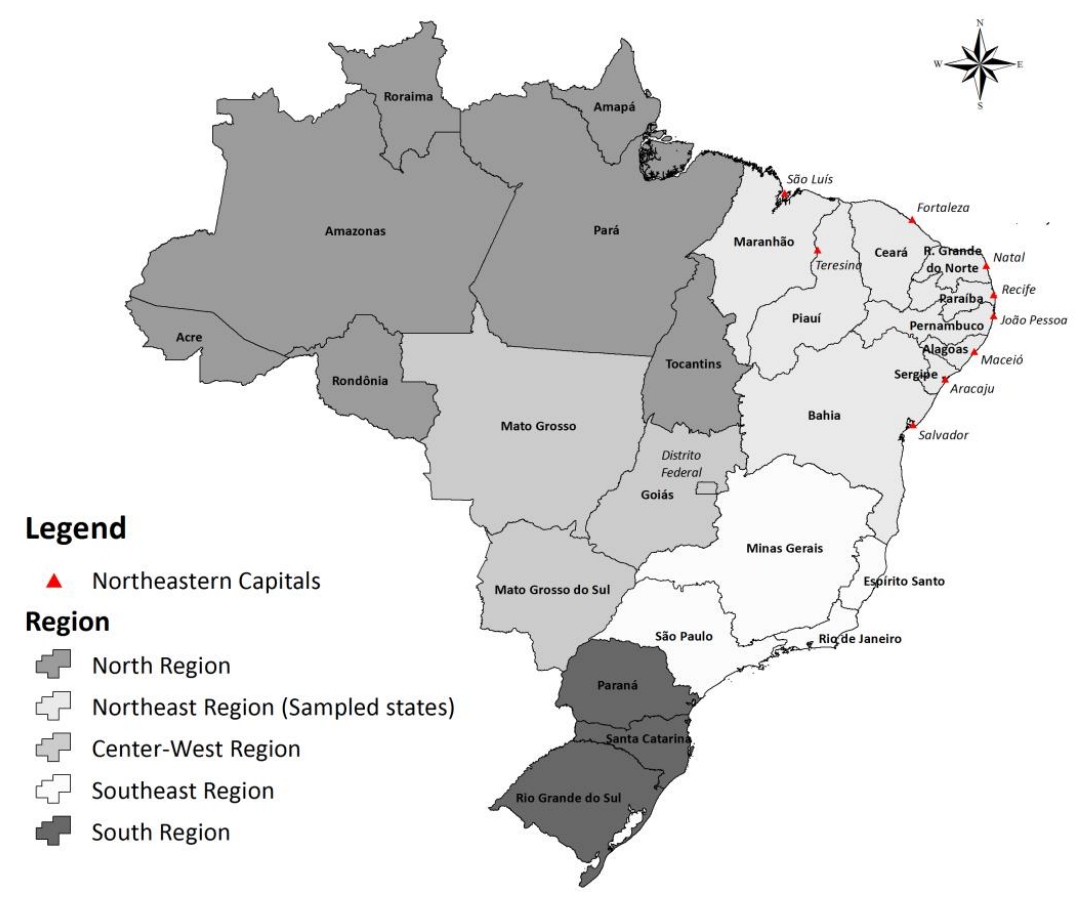

Table A2: Female population and survey participants by state capital

\begin{tabular}{lcc} 
& Female Population $15-49 *$ & Number of participants \\
\cline { 2 - 3 } Aracajú & 182,932 & 1,007 \\
Fortaleza & 763,145 & 1,221 \\
João Pessoa & 230,831 & 1,117 \\
Maceió & 295,015 & 1,018 \\
Natal & 251,401 & 1,078 \\
Recife & 471,612 & 1,308 \\
Salvador & 905,401 & 1,202 \\
São Luís & 342,191 & 1,143 \\
Teresina & 248,746 & 1,000 \\
\hline Total & $3,691,274$ & 10,094 \\
\hline *Pesquisa Nacional de Amostra por Domicílios Contínua/IBGE, 1st Quarter/2016.
\end{tabular}




\section{A.2. Data entry and analysis}

PCSVDF $^{\text {Mulher }}$ survey used CAPI (Computer - Assisted Personal Interviewing) data collection technology provided by means of the World Bank's Survey Solutions: a free computer-assisted personal interviewing software developed by the Development Research group of the World Bank in collaboration with the Food and Agriculture Organization (FAO). 


\section{B. ADDITIONAL RESULTS}

Table B1: Pairwise correlations for Zika incidence, preventive and reproductive behaviors

\begin{tabular}{|c|c|c|c|c|c|c|c|c|c|c|c|c|}
\hline & $\begin{array}{c}\text { Diagnosed } \\
\text { with Zika }\end{array}$ & $\begin{array}{c}\text { Zika } \\
\text { symptoms }\end{array}$ & $\begin{array}{l}\text { Zika in the } \\
\text { household }\end{array}$ & $\begin{array}{l}\text { Zika in the } \\
\text { neighborhood }\end{array}$ & $\begin{array}{l}\text { Home visit } \\
\text { from EDC } \\
\text { agent }\end{array}$ & $\begin{array}{l}\text { Long \& } \\
\text { light- } \\
\text { colored } \\
\text { clothes }\end{array}$ & $\begin{array}{l}\text { Mosquito } \\
\text { repellent / } \\
\text { Insecticides }\end{array}$ & $\begin{array}{l}\text { Protective } \\
\text { screens / } \\
\text { windows } \\
\text { closed } \\
\end{array}$ & $\begin{array}{l}\text { Dumped } \\
\text { standing } \\
\text { water }\end{array}$ & $\begin{array}{c}\text { Knows that } \\
\text { Zika virus may } \\
\text { cause } \\
\text { Microcephaly }\end{array}$ & $\begin{array}{l}\text { Currently } \\
\text { pregnant }\end{array}$ & $\begin{array}{l}\text { Currently } \\
\text { using } \\
\text { contraceptive }\end{array}$ \\
\hline Diagnosed with Zika & 1 & & & & & & & & & & & \\
\hline Zika symptoms & $0.646 * * *$ & 1 & & & & & & & & & & \\
\hline Zika in the household & $0.336 * * *$ & $0.262 * * *$ & 1 & & & & & & & & & \\
\hline Zika in the neighborhood & $0.227 * * *$ & $0.164 * * *$ & $0.416^{* * * *}$ & 1 & & & & & & & & \\
\hline Home visit from EDC agent & -0.008 & -0.014 & $0.062 * * *$ & $0.062 * * *$ & 1 & & & & & & & \\
\hline Long \& light-colored clothes & $0.032 * * *$ & $0.025^{* *}$ & $0.027 * * *$ & $0.024 * *$ & 0.009 & 1 & & & & & & \\
\hline Mosquito repellent/Insecticides & $0.024 * *$ & $0.033 * * *$ & $0.033^{* * * *}$ & $0.062 * * *$ & $0.027 * * *$ & $0.191 * * *$ & 1 & & & & & \\
\hline Protective screens/windows closed & 0.007 & $0.023^{* *}$ & -0.008 & 0.009 & -0.009 & $0.192 * * *$ & $0.288^{* * * *}$ & 1 & & & & \\
\hline Dumped standing water & $0.023 * *$ & $0.044 * * *$ & 0.015 & $0.064 * * *$ & $0.092 * * *$ & $0.053 * * *$ & $0.135^{* * * *}$ & $0.114 * * *$ & 1 & & & \\
\hline Zika may cause Microcephaly & $0.019 *$ & $0.018^{*}$ & $0.049 * * *$ & $0.077 * * *$ & $0.083 * * *$ & $-0.039 * * *$ & $0.022 * *$ & $-0.026 * *$ & $0.107 * * *$ & 1 & & \\
\hline Currently pregnant & -0.017 & $-0.031 * * *$ & 0.001 & 0.004 & 0.003 & $0.04 * * *$ & $0.108 * * *$ & $0.04 * * *$ & $0.025^{* *}$ & 0.006 & 1 & \\
\hline Currently using contraceptive & -0.012 & $-0.019 *$ & $0.02 *$ & 0.01 & 0.017 & $-0.021 *$ & $0.027 * *$ & -0.012 & 0.014 & $0.032 * * *$ & $-0.04 * * *$ & 1 \\
\hline $15-19$ & $-0.037 * * *$ & $-0.038 * * *$ & $0.026^{* * * *}$ & -0.003 & $-0.042 * * *$ & 0.004 & $-0.049 * * *$ & $-0.025 * *$ & $-0.047 * * *$ & $-0.036 * * *$ & $0.029 * * *$ & $0.062 * * *$ \\
\hline $20-24$ & 0.004 & -0.013 & -0.007 & $-0.02 *$ & $-0.02 * *$ & -0.004 & 0.013 & $0.022 * *$ & -0.013 & 0.0002 & $0.057 * * *$ & $0.112 * * *$ \\
\hline $25-29$ & 0.004 & $-0.022 * *$ & -0.007 & 0.01 & 0.004 & $-0.02 * *$ & $0.035 * * *$ & 0.006 & 0.004 & $0.02 * *$ & $0.037 * * *$ & $0.094 * * *$ \\
\hline $30-34$ & -0.013 & $-0.022 * *$ & 0.004 & -0.002 & 0.0004 & 0.005 & $0.031 * * *$ & $0.021 * *$ & $0.02 * *$ & 0.013 & 0.017 & $0.069 * * *$ \\
\hline $35-39$ & 0.011 & $0.025^{* *}$ & -0.003 & 0.012 & 0.007 & 0.008 & $0.025^{* *}$ & 0.007 & -0.002 & -0.006 & $-0.042 * * *$ & -0.009 \\
\hline $40-45$ & 0.015 & $0.028 * * *$ & 0.002 & -0.001 & $0.017 *$ & 0.011 & $-0.03 * * *$ & $-0.019 *$ & $0.017 *$ & 0.009 & $-0.035 * * *$ & $-0.098 * * *$ \\
\hline $45-49$ & 0.015 & $0.043 * * *$ & -0.014 & 0.002 & $0.033 * * *$ & -0.003 & $-0.03 * * *$ & -0.016 & $0.019 *$ & -0.004 & $-0.056 * * *$ & $-0.219 * * *$ \\
\hline White & $-0.032 * * *$ & $-0.026 * * *$ & $-0.03 * * *$ & -0.003 & $-0.058 * * *$ & 0.008 & 0.01 & 0.005 & -0.01 & -0.013 & -0.017 & $-0.025 * *$ \\
\hline Black & $0.036^{* * * *}$ & $0.022 * *$ & $0.032 * * *$ & $0.03 * * *$ & $0.029 * * *$ & $0.027 * * *$ & $0.022 * *$ & 0.01 & $-0.022 * *$ & $-0.041 * * *$ & -0.007 & 0.006 \\
\hline Brown & -0.002 & 0.005 & -0.0004 & $-0.021 * *$ & $0.026 * *$ & $-0.028 * * *$ & $-0.028 * * *$ & -0.013 & $0.027 * * *$ & $0.046 * * *$ & $0.02 *$ & 0.017 \\
\hline Asian/Indigenous & -0.008 & -0.006 & -0.002 & -0.01 & -0.008 & -0.007 & 0.003 & 0.005 & 0.005 & -0.001 & 0.001 & -0.01 \\
\hline No schooling/Incomplete Primary & 0.016 & $0.038 * * *$ & -0.012 & -0.007 & $-0.035 * * *$ & $-0.041 * * *$ & $-0.084 * * *$ & $-0.032 * * *$ & $-0.06 * * *$ & $-0.034 * * *$ & 0.0004 & $-0.065 * * *$ \\
\hline Fundamental school & 0.01 & 0.008 & 0.014 & -0.013 & $-0.026 * * *$ & -0.005 & $-0.045 * * *$ & -0.015 & $-0.017 *$ & $-0.036 * * *$ & $0.019 *$ & 0.002 \\
\hline High school & 0.005 & 0.002 & 0.013 & $0.019 *$ & $0.049 * * *$ & 0.007 & $0.058 * * *$ & 0.011 & $0.046 * * *$ & $0.044 * * *$ & -0.007 & $0.04 * * *$ \\
\hline College education & $-0.041 * * *$ & $-0.062 * * *$ & $-0.025 * *$ & -0.005 & -0.002 & $0.045 * * *$ & $0.071 * * *$ & $0.041 * * *$ & $0.021 * *$ & $0.019 *$ & -0.014 & 0.015 \\
\hline Aracaju & $-0.093 * * *$ & -0.016 & $-0.11 * * *$ & $-0.15 * * *$ & $0.054 * * *$ & -0.012 & 0.014 & -0.007 & 0.008 & -0.015 & 0.003 & $0.04 * * *$ \\
\hline Fortaleza & $-0.087 * * *$ & $-0.098 * * *$ & $-0.078 * * *$ & $-0.152 * * *$ & 0.001 & $-0.052 * * *$ & $-0.077 * * *$ & $-0.05 * * *$ & $-0.09 * * *$ & $-0.02 *$ & 0.016 & 0.017 \\
\hline João Pessoa & $0.031 * * *$ & $0.034 * * *$ & 0.013 & $0.081 * * *$ & $-0.092 * * *$ & $-0.022 * *$ & $-0.022 * *$ & 0.007 & $0.026 * * *$ & 0.015 & -0.007 & -0.016 \\
\hline Maceió & $0.072 * * *$ & $0.031 * * *$ & $0.085^{* * * *}$ & $0.127 * * *$ & $-0.153^{* * *}$ & $0.036 * * *$ & $0.057 * * *$ & $0.076 * * *$ & $-0.037 * * *$ & $0.023 * *$ & -0.001 & $-0.026^{* *}$ \\
\hline Natal & -0.015 & 0.01 & 0.014 & $0.059 * * *$ & $-0.042 * * *$ & $0.019^{*}$ & -0.002 & -0.002 & $0.041 * * *$ & $0.023 * *$ & 0.016 & $0.033^{* * * *}$ \\
\hline Recife & $-0.064 * * *$ & $-0.022 * *$ & $-0.03 * * *$ & $0.028 * * *$ & -0.003 & $0.039 * * *$ & $0.072 * * *$ & 0.004 & -0.005 & $-0.034 * * *$ & $-0.024 * *$ & -0.005 \\
\hline Salvador & $0.098 * * *$ & $0.053 * * *$ & $0.099 * * *$ & $0.06 * * *$ & $0.058 * * *$ & $0.032 * * *$ & $0.034 * * *$ & $-0.029 * * *$ & $-0.042 * * *$ & $-0.047 * * *$ & 0.013 & $0.049 * * *$ \\
\hline São Luís & $0.159 * * *$ & $0.078 * * *$ & $0.134 * * *$ & $0.149 * * *$ & $0.073 * * *$ & $-0.033 * * *$ & 0.013 & $0.052 * * *$ & $0.071 * * *$ & $0.042 * * *$ & -0.006 & $-0.052 * * *$ \\
\hline Teresina & $-0.105 * * *$ & $-0.07 * * *$ & $-0.136 * * *$ & $-0.212 * * *$ & $0.102 * * *$ & -0.007 & $-0.094 * * *$ & $-0.05 * * *$ & $0.033^{* * * *}$ & $0.019 * *$ & -0.01 & $-0.043 * * *$ \\
\hline
\end{tabular}

$* \mathrm{p}<0.10 . * * \mathrm{p}<0.05, * * * \mathrm{p}<0.01$ 


\begin{tabular}{|c|c|c|c|c|c|}
\hline \multicolumn{6}{|c|}{ Table B2: OLS regressions of Zika incidence } \\
\hline & $\begin{array}{l}\text { Diagnosed } \\
\text { with Zika }\end{array}$ & $\begin{array}{c}\text { Zika } \\
\text { symptoms }\end{array}$ & $\begin{array}{l}\text { Zika in the } \\
\text { household }\end{array}$ & $\begin{array}{l}\text { Zika in the } \\
\text { neighborhood }\end{array}$ & $\begin{array}{c}\text { Home visit } \\
\text { from EDC } \\
\text { agent }\end{array}$ \\
\hline \multirow[t]{2}{*}{$20-24$} & $0.062 * * *$ & $0.047 * * *$ & $-0.032 *$ & -0.020 & 0.022 \\
\hline & $(0.015)$ & $(0.018)$ & $(0.019)$ & $(0.018)$ & $(0.019)$ \\
\hline \multirow[t]{2}{*}{$25-29$} & $0.063 * * *$ & $0.045^{* *}$ & $-0.033^{*}$ & 0.012 & $0.053 * * *$ \\
\hline & $(0.016)$ & $(0.018)$ & $(0.019)$ & $(0.018)$ & $(0.019)$ \\
\hline \multirow[t]{2}{*}{$30-34$} & $0.047 * * *$ & $0.046^{* *}$ & -0.019 & 0.002 & $0.043 * *$ \\
\hline & $(0.015)$ & $(0.018)$ & $(0.019)$ & $(0.018)$ & $(0.019)$ \\
\hline \multirow[t]{2}{*}{$35-39$} & $0.068 * * *$ & $0.092 * * *$ & -0.029 & 0.015 & $0.054 * * *$ \\
\hline & $(0.016)$ & $(0.019)$ & $(0.019)$ & $(0.018)$ & $(0.019)$ \\
\hline \multirow[t]{2}{*}{$40-45$} & $0.076 * * *$ & $0.098 * * *$ & -0.020 & 0.005 & $0.064 * * *$ \\
\hline & $(0.017)$ & $(0.019)$ & $(0.020)$ & $(0.019)$ & $(0.020)$ \\
\hline \multirow[t]{2}{*}{$45-49$} & $0.074 * * *$ & $0.109 * * *$ & $-0.032 *$ & 0.015 & $0.089 * * *$ \\
\hline & $(0.016)$ & $(0.018)$ & $(0.019)$ & $(0.017)$ & $(0.019)$ \\
\hline \multirow[t]{2}{*}{ Black } & 0.006 & 0.012 & 0.013 & 0.017 & $0.035 * *$ \\
\hline & $(0.013)$ & $(0.015)$ & $(0.015)$ & $(0.014)$ & $(0.015)$ \\
\hline \multirow[t]{2}{*}{ Brown } & 0.015 & $0.022 *$ & $0.027 * *$ & 0.017 & $0.043 * * *$ \\
\hline & $(0.010)$ & $(0.012)$ & $(0.012)$ & $(0.011)$ & $(0.012)$ \\
\hline \multirow[t]{2}{*}{ Asian/Indigenous } & -0.025 & -0.022 & 0.015 & -0.060 & -0.017 \\
\hline & $(0.055)$ & $(0.067)$ & $(0.070)$ & $(0.066)$ & $(0.072)$ \\
\hline \multirow[t]{2}{*}{ Fundamental school } & -0.010 & -0.018 & 0.006 & -0.011 & 0.014 \\
\hline & $(0.014)$ & $(0.016)$ & $(0.016)$ & $(0.015)$ & $(0.016)$ \\
\hline \multirow[t]{2}{*}{ High school education } & $-0.040 * * *$ & $-0.045^{* * *}$ & -0.006 & -0.003 & $0.048 * * *$ \\
\hline & $(0.012)$ & $(0.014)$ & $(0.014)$ & $(0.013)$ & $(0.014)$ \\
\hline \multirow[t]{2}{*}{ College education } & $-0.098 * * *$ & $-0.139 * * *$ & $-0.045^{* *}$ & -0.030 & 0.030 \\
\hline & $(0.016)$ & $(0.019)$ & $(0.020)$ & $(0.019)$ & $(0.020)$ \\
\hline \multirow[t]{2}{*}{ Aracaju } & 0.012 & $0.075 * * *$ & $0.036^{*}$ & $0.092 * * *$ & $-0.069 * * *$ \\
\hline & $(0.014)$ & $(0.020)$ & $(0.021)$ & $(0.023)$ & $(0.021)$ \\
\hline \multirow[t]{2}{*}{ Fortaleza } & $0.033 * *$ & -0.022 & $0.092 * * *$ & $0.108 * * *$ & $-0.146 * * *$ \\
\hline & $(0.014)$ & $(0.019)$ & $(0.020)$ & $(0.022)$ & $(0.020)$ \\
\hline \multirow[t]{2}{*}{ João Pessoa } & $0.175^{* * * *}$ & $0.153 * * *$ & $0.227 * * *$ & $0.412 * * *$ & $-0.270 * * *$ \\
\hline & $(0.017)$ & $(0.020)$ & $(0.021)$ & $(0.020)$ & $(0.021)$ \\
\hline \multirow[t]{2}{*}{ Maceió } & $0.226 * * *$ & $0.150 * * *$ & $0.333 * * *$ & $0.476 * * *$ & $-0.370 * * *$ \\
\hline & $(0.018)$ & $(0.021)$ & $(0.021)$ & $(0.020)$ & $(0.021)$ \\
\hline \multirow[t]{2}{*}{ Natal } & $0.118 * * *$ & $0.121 * * *$ & $0.226 * * *$ & $0.389 * * *$ & $-0.199 * * *$ \\
\hline & $(0.016)$ & $(0.020)$ & $(0.021)$ & $(0.021)$ & $(0.021)$ \\
\hline \multirow[t]{2}{*}{ Recife } & $0.065 * * *$ & $0.080 * * *$ & $0.166^{* * * *}$ & $0.337 * * *$ & $-0.148 * * *$ \\
\hline & $(0.014)$ & $(0.019)$ & $(0.020)$ & $(0.020)$ & $(0.020)$ \\
\hline \multirow[t]{2}{*}{ Salvador } & $0.247 * * *$ & $0.172 * * *$ & $0.336 * * *$ & $0.376 * * *$ & $-0.077 * * *$ \\
\hline & $(0.017)$ & $(0.021)$ & $(0.021)$ & $(0.021)$ & $(0.020)$ \\
\hline \multirow[t]{2}{*}{ São Luís } & $0.329 * * *$ & $0.220 * * *$ & $0.392 * * *$ & $0.495 * * *$ & $-0.058 * * *$ \\
\hline & $(0.018)$ & $(0.020)$ & $(0.020)$ & $(0.019)$ & $(0.020)$ \\
\hline \multicolumn{6}{|l|}{ Joint significance test } \\
\hline Education variables $\chi^{2}(3)$ & $14.33 * * *$ & $20.72 * * *$ & $2.41 *$ & 1.08 & $5.01 * * *$ \\
\hline Mean & 0.233 & 0.348 & 0.486 & 0.672 & 0.594 \\
\hline $\mathrm{R}^{2}$ & 0.071 & 0.035 & 0.067 & 0.130 & 0.055 \\
\hline Observations & 9765 & 9820 & 9797 & 9483 & 9686 \\
\hline
\end{tabular}

Robust standard errors in parentheses.

$* \mathrm{p}<0.10 . * * \mathrm{p}<0.05, * * * \mathrm{p}<0.01$ 


\begin{tabular}{|c|c|c|c|c|}
\hline \multicolumn{5}{|c|}{ Table B3: OLS regressions of Zika preventive behaviors } \\
\hline & $\begin{array}{l}\text { Long \& light- } \\
\text { colored clothes }\end{array}$ & $\begin{array}{l}\text { Mosquito repellent / } \\
\text { Insecticides }\end{array}$ & $\begin{array}{c}\text { Protective screens / } \\
\text { windows closed }\end{array}$ & $\begin{array}{c}\text { Dumped } \\
\text { standing water }\end{array}$ \\
\hline \multirow[t]{2}{*}{$20-24$} & -0.010 & $0.046^{* * *}$ & $0.037 * * *$ & 0.028 \\
\hline & $(0.011)$ & $(0.015)$ & $(0.013)$ & $(0.017)$ \\
\hline \multirow[t]{2}{*}{$25-29$} & $-0.026 * *$ & $0.056 * * *$ & 0.015 & $0.045 * * *$ \\
\hline & $(0.011)$ & $(0.015)$ & $(0.013)$ & $(0.017)$ \\
\hline \multirow[t]{2}{*}{$30-34$} & -0.009 & $0.055 * * *$ & $0.031^{* *}$ & $0.062 * * *$ \\
\hline & $(0.011)$ & $(0.015)$ & $(0.013)$ & $(0.017)$ \\
\hline \multirow[t]{2}{*}{$35-39$} & -0.006 & $0.055 * * *$ & $0.023^{*}$ & $0.038 * *$ \\
\hline & $(0.012)$ & $(0.015)$ & $(0.013)$ & $(0.017)$ \\
\hline \multirow[t]{2}{*}{$40-45$} & 0.001 & 0.010 & 0.004 & $0.070 * * *$ \\
\hline & $(0.012)$ & $(0.015)$ & $(0.013)$ & $(0.017)$ \\
\hline \multirow[t]{2}{*}{$45-49$} & -0.009 & 0.020 & 0.007 & $0.068 * * *$ \\
\hline & $(0.011)$ & $(0.015)$ & $(0.013)$ & $(0.017)$ \\
\hline \multirow[t]{2}{*}{ Black } & 0.010 & 0.007 & 0.014 & 0.001 \\
\hline & $(0.009)$ & $(0.013)$ & $(0.011)$ & $(0.013)$ \\
\hline \multirow[t]{2}{*}{ Brown } & -0.004 & -0.003 & 0.001 & $0.028 * * *$ \\
\hline & $(0.007)$ & $(0.010)$ & $(0.009)$ & $(0.010)$ \\
\hline \multirow[t]{2}{*}{ Asian/Indigenous } & -0.032 & -0.011 & 0.020 & 0.040 \\
\hline & $(0.037)$ & $(0.058)$ & $(0.055)$ & $(0.058)$ \\
\hline \multirow[t]{2}{*}{ Fundamental school } & $0.022^{* *}$ & $0.046 * * *$ & 0.015 & $0.048 * * *$ \\
\hline & $(0.009)$ & $(0.012)$ & $(0.011)$ & $(0.014)$ \\
\hline \multirow[t]{2}{*}{ High school education } & $0.031 * * *$ & $0.090 * * *$ & $0.020^{* *}$ & $0.066 * * *$ \\
\hline & $(0.008)$ & $(0.011)$ & $(0.009)$ & $(0.012)$ \\
\hline \multirow[t]{2}{*}{ College education } & $0.069 * * *$ & $0.152 * * *$ & $0.057 * * *$ & $0.059 * * *$ \\
\hline & $(0.012)$ & $(0.017)$ & $(0.015)$ & $(0.017)$ \\
\hline \multirow[t]{2}{*}{ Aracaju } & -0.002 & $0.140 * * *$ & $0.046 * * *$ & -0.023 \\
\hline & $(0.012)$ & $(0.016)$ & $(0.014)$ & $(0.018)$ \\
\hline \multirow[t]{2}{*}{ Fortaleza } & $-0.029 * * *$ & $0.042 * * *$ & 0.011 & $-0.128 * * *$ \\
\hline & $(0.011)$ & $(0.014)$ & $(0.013)$ & $(0.018)$ \\
\hline \multirow[t]{2}{*}{ João Pessoa } & -0.008 & $0.093 * * *$ & $0.059 * * *$ & -0.005 \\
\hline & $(0.012)$ & $(0.015)$ & $(0.014)$ & $(0.017)$ \\
\hline \multirow[t]{2}{*}{ Maceió } & $0.041 * * *$ & $0.186^{* * *}$ & $0.130 * * *$ & $-0.077 * * *$ \\
\hline & $(0.014)$ & $(0.017)$ & $(0.016)$ & $(0.019)$ \\
\hline \multirow[t]{2}{*}{ Natal } & $0.023^{*}$ & $0.117 * * *$ & $0.052 * * *$ & 0.016 \\
\hline & $(0.013)$ & $(0.016)$ & $(0.014)$ & $(0.017)$ \\
\hline \multirow[t]{2}{*}{ Recife } & $0.038 * * *$ & $0.194 * * *$ & $0.057 * * *$ & $-0.038 * *$ \\
\hline & $(0.013)$ & $(0.016)$ & $(0.013)$ & $(0.017)$ \\
\hline \multirow[t]{2}{*}{ Salvador } & $0.029 * *$ & $0.153 * * *$ & $0.022 *$ & $-0.078 * * *$ \\
\hline & $(0.013)$ & $(0.016)$ & $(0.013)$ & $(0.018)$ \\
\hline \multirow[t]{2}{*}{ São Luís } & $-0.024 * *$ & $0.116 * * *$ & $0.097 * * *$ & $0.037 * *$ \\
\hline & $(0.012)$ & $(0.016)$ & $(0.015)$ & $(0.016)$ \\
\hline \multicolumn{5}{|l|}{ Joint significance test } \\
\hline Education variables $\chi^{2}(3)$ & $11.62 * * *$ & $37.29 * * *$ & $5.18^{* * * *}$ & $9.36^{* * * *}$ \\
\hline Mean & 0.089 & 0.208 & 0.140 & 0.787 \\
\hline $\mathrm{R}^{2}$ & 0.012 & 0.039 & 0.016 & 0.023 \\
\hline Observations & 9738 & 9787 & 9771 & 9738 \\
\hline
\end{tabular}

Robust standard errors in parentheses.

$* \mathrm{p}<0.10 . * * \mathrm{p}<0.05, * * * \mathrm{p}<0.01$ 


\begin{tabular}{|c|c|c|c|}
\hline \multicolumn{4}{|c|}{ Table B4: OLS regressions of reproductive behaviors } \\
\hline & $\begin{array}{l}\text { Knows that Zika virus } \\
\text { may cause Microcephaly }\end{array}$ & $\begin{array}{l}\text { Currently } \\
\text { pregnant }\end{array}$ & $\begin{array}{l}\text { Currently using } \\
\text { contraceptive }\end{array}$ \\
\hline \multirow[t]{2}{*}{$20-24$} & 0.012 & 0.010 & 0.017 \\
\hline & $(0.008)$ & $(0.012)$ & $(0.024)$ \\
\hline \multirow[t]{2}{*}{$25-29$} & $0.022 * * *$ & 0.001 & -0.011 \\
\hline & $(0.008)$ & $(0.012)$ & $(0.024)$ \\
\hline \multirow[t]{2}{*}{$30-34$} & $0.020 * *$ & -0.009 & $-0.043 *$ \\
\hline & $(0.008)$ & $(0.011)$ & $(0.024)$ \\
\hline \multirow[t]{2}{*}{$35-39$} & 0.011 & $-0.037 * * *$ & $-0.127 * * *$ \\
\hline & $(0.009)$ & $(0.011)$ & $(0.024)$ \\
\hline \multirow[t]{2}{*}{$40-45$} & $0.020 * *$ & $-0.036 * * *$ & $-0.238 * * *$ \\
\hline & $(0.008)$ & $(0.011)$ & $(0.024)$ \\
\hline \multirow[t]{2}{*}{$45-49$} & $0.014 *$ & $-0.044 * * *$ & $-0.365 * * *$ \\
\hline & $(0.009)$ & $(0.010)$ & $(0.023)$ \\
\hline \multirow[t]{2}{*}{ Black } & -0.004 & 0.000 & 0.010 \\
\hline & $(0.006)$ & $(0.007)$ & $(0.016)$ \\
\hline \multirow[t]{2}{*}{ Brown } & $0.016 * * *$ & 0.007 & $0.023^{*}$ \\
\hline & $(0.005)$ & $(0.005)$ & $(0.013)$ \\
\hline \multirow[t]{2}{*}{ Asian/Indigenous } & 0.008 & 0.007 & -0.081 \\
\hline & $(0.029)$ & $(0.032)$ & $(0.073)$ \\
\hline \multirow[t]{2}{*}{ Fundamental school } & 0.003 & -0.001 & 0.018 \\
\hline & $(0.007)$ & $(0.008)$ & $(0.017)$ \\
\hline \multirow[t]{2}{*}{ High school education } & $0.020 * * *$ & -0.009 & $0.044 * * *$ \\
\hline & $(0.006)$ & $(0.006)$ & $(0.015)$ \\
\hline \multirow[t]{2}{*}{ College education } & $0.019 * *$ & -0.012 & $0.071 * * *$ \\
\hline & $(0.008)$ & $(0.008)$ & $(0.021)$ \\
\hline \multirow[t]{2}{*}{ Aracaju } & $-0.016^{*}$ & 0.007 & $0.116 * * *$ \\
\hline & $(0.009)$ & $(0.010)$ & $(0.024)$ \\
\hline \multirow[t]{2}{*}{ Fortaleza } & $-0.019 * *$ & 0.011 & $0.065 * * *$ \\
\hline & $(0.008)$ & $(0.010)$ & $(0.022)$ \\
\hline \multirow[t]{2}{*}{ João Pessoa } & -0.001 & 0.000 & 0.030 \\
\hline & $(0.008)$ & $(0.009)$ & $(0.023)$ \\
\hline \multirow[t]{2}{*}{ Maceió } & 0.004 & 0.005 & 0.013 \\
\hline & $(0.007)$ & $(0.010)$ & $(0.023)$ \\
\hline \multirow[t]{2}{*}{ Natal } & 0.005 & 0.016 & $0.108 * * *$ \\
\hline & $(0.007)$ & $(0.010)$ & $(0.023)$ \\
\hline \multirow[t]{2}{*}{ Recife } & $-0.025 * * *$ & -0.008 & $0.046 * *$ \\
\hline & $(0.008)$ & $(0.009)$ & $(0.022)$ \\
\hline \multirow[t]{2}{*}{ Salvador } & $-0.030 * * *$ & 0.013 & $0.120 * * *$ \\
\hline & $(0.008)$ & $(0.009)$ & $(0.023)$ \\
\hline \multirow[t]{2}{*}{ São Luís } & $0.011 *$ & 0.003 & -0.034 \\
\hline & $(0.006)$ & $(0.009)$ & $(0.023)$ \\
\hline \multicolumn{4}{|l|}{ Joint significance test } \\
\hline Education variables $\chi^{2}(3)$ & $5.87 * * *$ & 1.32 & $5.23 * * *$ \\
\hline Mean & 0.961 & 0.043 & 0.509 \\
\hline $\mathrm{R}^{2}$ & 0.012 & 0.012 & 0.087 \\
\hline Observations & 9825 & 8434 & 8397 \\
\hline
\end{tabular}

Robust standard errors in parentheses.

$* \mathrm{p}<0.10 . * * \mathrm{p}<0.05, * * * \mathrm{p}<0.01$ 


\begin{tabular}{|c|c|c|c|c|c|}
\hline \multicolumn{6}{|c|}{ Table B5: OLS regressions of Zika incidence, accounting for domestic violence in the last 12 months } \\
\hline & $\begin{array}{c}\text { Diagnosed } \\
\text { with Zika }\end{array}$ & $\begin{array}{c}\text { Zika } \\
\text { symptoms }\end{array}$ & $\begin{array}{l}\text { Zika in the } \\
\text { household }\end{array}$ & $\begin{array}{l}\text { Zika in the } \\
\text { neighborhood }\end{array}$ & $\begin{array}{l}\text { Home visit } \\
\text { from EDC } \\
\text { agent }\end{array}$ \\
\hline 20-24 & $\begin{array}{c}0.064 * * * \\
(0.022)\end{array}$ & $\begin{array}{l}0.046^{*} \\
(0.025)\end{array}$ & $\begin{array}{l}-0.052^{*} \\
(0.026)\end{array}$ & $\begin{array}{c}-0.053 * * \\
(0.024)\end{array}$ & $\begin{array}{c}0.023 \\
(0.027)\end{array}$ \\
\hline 25-29 & $\begin{array}{c}0.068 * * * \\
(0.022)\end{array}$ & $\begin{array}{c}0.050 * * \\
(0.025)\end{array}$ & $\begin{array}{l}-0.050^{*} \\
(0.026)\end{array}$ & $\begin{array}{l}-0.036 \\
(0.024)\end{array}$ & $\begin{array}{c}0.073 * * * \\
(0.026)\end{array}$ \\
\hline $30-34$ & $\begin{array}{c}0.058 * * * \\
(0.022)\end{array}$ & $\begin{array}{c}0.054 * * \\
(0.025)\end{array}$ & $\begin{array}{l}-0.043 \\
(0.026)\end{array}$ & $\begin{array}{c}-0.049 * * \\
(0.024)\end{array}$ & $\begin{array}{c}0.042 \\
(0.027)\end{array}$ \\
\hline 35-39 & $\begin{array}{c}0.054 * * \\
(0.022)\end{array}$ & $\begin{array}{c}0.095^{* * *} * \\
(0.026)\end{array}$ & $\begin{array}{c}-0.063 * * \\
(0.027)\end{array}$ & $\begin{array}{l}-0.041^{*} \\
(0.025)\end{array}$ & $\begin{array}{c}0.068^{* * *} \\
(0.027)\end{array}$ \\
\hline $40-45$ & $\begin{array}{l}0.058 * * \\
(0.023)\end{array}$ & $\begin{array}{c}0.097 * * * \\
(0.027)\end{array}$ & $\begin{array}{l}-0.039 \\
(0.028)\end{array}$ & $\begin{array}{l}-0.035 \\
(0.025)\end{array}$ & $\begin{array}{l}0.054^{*} \\
(0.028)\end{array}$ \\
\hline 45-49 & $\begin{array}{c}0.079 * * * \\
(0.022)\end{array}$ & $\begin{array}{c}0.111 * * * \\
(0.026)\end{array}$ & $\begin{array}{l}-0.036 \\
(0.027)\end{array}$ & $\begin{array}{l}-0.023 \\
(0.024)\end{array}$ & $\begin{array}{c}0.095^{* * *} * \\
(0.027)\end{array}$ \\
\hline Black & $\begin{array}{c}-0.001 \\
(0.017)\end{array}$ & $\begin{array}{c}0.007 \\
(0.019)\end{array}$ & $\begin{array}{c}0.020 \\
(0.020)\end{array}$ & $\begin{array}{c}0.011 \\
(0.018)\end{array}$ & $\begin{array}{c}0.042 * * \\
(0.020)\end{array}$ \\
\hline Brown & $\begin{array}{c}0.016 \\
(0.014)\end{array}$ & $\begin{array}{c}0.024 \\
(0.016)\end{array}$ & $\begin{array}{c}0.036^{* * *} \\
(0.017)\end{array}$ & $\begin{array}{c}0.002 \\
(0.015)\end{array}$ & $\begin{array}{c}0.042 * * \\
(0.017)\end{array}$ \\
\hline Asian/Indigenous & $\begin{array}{l}-0.071 \\
(0.074)\end{array}$ & $\begin{array}{l}-0.060 \\
(0.099)\end{array}$ & $\begin{array}{l}-0.060 \\
(0.103)\end{array}$ & $\begin{array}{l}-0.131 \\
(0.102)\end{array}$ & $\begin{array}{c}0.086 \\
(0.098)\end{array}$ \\
\hline Fundamental school & $\begin{array}{c}0.003 \\
(0.018)\end{array}$ & $\begin{array}{l}-0.000 \\
(0.020)\end{array}$ & $\begin{array}{l}-0.006 \\
(0.021)\end{array}$ & $\begin{array}{l}-0.001 \\
(0.020)\end{array}$ & $\begin{array}{l}-0.002 \\
(0.021)\end{array}$ \\
\hline High school education & $\begin{array}{l}-0.015 \\
(0.015)\end{array}$ & $\begin{array}{l}-0.022 \\
(0.018)\end{array}$ & $\begin{array}{l}-0.012 \\
(0.018)\end{array}$ & $\begin{array}{c}0.025 \\
(0.017)\end{array}$ & $\begin{array}{c}0.058 * * * \\
(0.018)\end{array}$ \\
\hline College education & $\begin{array}{c}-0.089 * * * \\
(0.021)\end{array}$ & $\begin{array}{c}-0.144 * * * \\
(0.024)\end{array}$ & $\begin{array}{c}-0.060 * * \\
(0.026)\end{array}$ & $\begin{array}{l}-0.018 \\
(0.025)\end{array}$ & $\begin{array}{c}0.038 \\
(0.025)\end{array}$ \\
\hline Emotional violence & $\begin{array}{c}-0.032 * \\
(0.019)\end{array}$ & $\begin{array}{c}0.002 \\
(0.023)\end{array}$ & $\begin{array}{c}0.013 \\
(0.025)\end{array}$ & $\begin{array}{c}0.029 \\
(0.022)\end{array}$ & $\begin{array}{l}-0.030 \\
(0.024)\end{array}$ \\
\hline Physical violence & $\begin{array}{c}0.010 \\
(0.030)\end{array}$ & $\begin{array}{c}0.015 \\
(0.035)\end{array}$ & $\begin{array}{c}0.021 \\
(0.036)\end{array}$ & $\begin{array}{l}-0.018 \\
(0.033)\end{array}$ & $\begin{array}{c}0.036 \\
(0.035)\end{array}$ \\
\hline Sexual violence & $\begin{array}{c}0.102 * * \\
(0.044)\end{array}$ & $\begin{array}{l}0.081^{*} \\
(0.047)\end{array}$ & $\begin{array}{c}0.018 \\
(0.047)\end{array}$ & $\begin{array}{c}0.030 \\
(0.046)\end{array}$ & $\begin{array}{l}-0.009 \\
(0.048)\end{array}$ \\
\hline Aracaju & $\begin{array}{c}0.005 \\
(0.018)\end{array}$ & $\begin{array}{c}0.061 * * \\
(0.028)\end{array}$ & $\begin{array}{c}0.035 \\
(0.029)\end{array}$ & $\begin{array}{c}0.015 \\
(0.031)\end{array}$ & $\begin{array}{l}-0.030 \\
(0.028)\end{array}$ \\
\hline Fortaleza & $\begin{array}{l}0.035^{*} \\
(0.018)\end{array}$ & $\begin{array}{c}-0.042 * \\
(0.025)\end{array}$ & $\begin{array}{l}0.045^{*} \\
(0.027)\end{array}$ & $\begin{array}{c}0.027 \\
(0.029)\end{array}$ & $\begin{array}{c}-0.127 * * * \\
(0.027)\end{array}$ \\
\hline João Pessoa & $\begin{array}{c}0.182 * * * \\
(0.021)\end{array}$ & $\begin{array}{c}0.156 * * * \\
(0.027)\end{array}$ & $\begin{array}{c}0.200 * * * \\
(0.028)\end{array}$ & $\begin{array}{c}0.363 * * * \\
(0.028)\end{array}$ & $\begin{array}{c}-0.259 * * * \\
(0.028)\end{array}$ \\
\hline Maceió & $\begin{array}{c}0.216^{* * * *} \\
(0.023)\end{array}$ & $\begin{array}{c}0.116 * * * \\
(0.028)\end{array}$ & $\begin{array}{c}0.296 * * * \\
(0.029)\end{array}$ & $\begin{array}{c}0.434 * * * \\
(0.027)\end{array}$ & $\begin{array}{c}-0.356^{* * *} * \\
(0.028)\end{array}$ \\
\hline Natal & $\begin{array}{c}0.102 * * * \\
(0.024)\end{array}$ & $\begin{array}{c}0.147 * * * \\
(0.031)\end{array}$ & $\begin{array}{c}0.206 * * * \\
(0.033)\end{array}$ & $\begin{array}{c}0.312 * * * \\
(0.033)\end{array}$ & $\begin{array}{c}-0.179 * * * \\
(0.033)\end{array}$ \\
\hline Recife & $\begin{array}{c}0.049 * * \\
(0.020)\end{array}$ & $\begin{array}{c}0.098 * * * \\
(0.029)\end{array}$ & $\begin{array}{c}0.103 * * * \\
(0.030)\end{array}$ & $\begin{array}{c}0.267 * * * \\
(0.031)\end{array}$ & $\begin{array}{c}-0.141 * * * \\
(0.030)\end{array}$ \\
\hline Salvador & $\begin{array}{c}0.242 * * * \\
(0.022)\end{array}$ & $\begin{array}{c}0.154 * * * \\
(0.027)\end{array}$ & $\begin{array}{c}0.330 * * * \\
(0.027)\end{array}$ & $\begin{array}{c}0.337 * * * \\
(0.028)\end{array}$ & $\begin{array}{c}-0.058 * * \\
(0.027)\end{array}$ \\
\hline São Luís & $\begin{array}{c}0.356 * * * \\
(0.023)\end{array}$ & $\begin{array}{c}0.215^{* * *} * \\
(0.028)\end{array}$ & $\begin{array}{c}0.387 * * * \\
(0.028)\end{array}$ & $\begin{array}{c}0.460 * * * \\
(0.026)\end{array}$ & $\begin{array}{l}-0.042 \\
(0.027)\end{array}$ \\
\hline Joint significance test & & & & & \\
\hline Education variables $\chi^{2}(3)$ & $8.34 * * *$ & $15.50 * * *$ & 2.05 & $2.11 *$ & $5.81 * * *$ \\
\hline Domestic violence variables $\chi^{2}(3)$ & $2.49^{*}$ & 1.48 & 0.62 & 0.84 & 0.61 \\
\hline Mean & 0.236 & 0.351 & 0.493 & 0.674 & 0.586 \\
\hline $\mathrm{R}^{2}$ & 0.081 & 0.039 & 0.074 & 0.140 & 0.061 \\
\hline Observations & 5630 & 5670 & 5660 & 5457 & 5589 \\
\hline
\end{tabular}

Robust standard errors in parentheses.

$* p<0.10 . * * p<0.05, * * * p<0.01$ 


\begin{tabular}{|c|c|c|c|c|}
\hline \multicolumn{5}{|c|}{ Table B6: OLS regressions of Zika preventive behaviors, accounting for domestic violence in the last 12 months } \\
\hline & $\begin{array}{l}\text { Long \& light-colored } \\
\text { clothes }\end{array}$ & $\begin{array}{l}\text { Mosquito repellent / } \\
\text { Insecticides }\end{array}$ & $\begin{array}{l}\text { Protective screens } \\
\text { / windows closed }\end{array}$ & $\begin{array}{c}\text { Dumped } \\
\text { standing water }\end{array}$ \\
\hline $20-24$ & $\begin{array}{l}-0.004 \\
(0.015)\end{array}$ & $\begin{array}{c}0.021 \\
(0.021)\end{array}$ & $\begin{array}{c}0.043^{* *} \\
(0.018)\end{array}$ & $\begin{array}{l}0.032 \\
(0.024)\end{array}$ \\
\hline \multirow[t]{2}{*}{$25-29$} & $-0.025^{*}$ & $0.041^{*}$ & $0.031^{*}$ & 0.031 \\
\hline & (0.014) & $(0.021)$ & $(0.017)$ & $(0.024)$ \\
\hline $30-34$ & $\begin{array}{c}0.006 \\
(0.015)\end{array}$ & $\begin{array}{c}0.028 \\
(0.021)\end{array}$ & $\begin{array}{l}0.033^{*} \\
(0.018)\end{array}$ & $\begin{array}{l}0.041^{*} \\
(0.024)\end{array}$ \\
\hline $35-39$ & $\begin{array}{l}-0.007 \\
(0.015)\end{array}$ & $\begin{array}{c}0.009 \\
(0.021)\end{array}$ & $\begin{array}{l}0.034^{*} \\
(0.018)\end{array}$ & $\begin{array}{l}0.042^{*} \\
(0.024)\end{array}$ \\
\hline $40-45$ & $\begin{array}{c}0.018 \\
(0.016)\end{array}$ & $\begin{array}{l}-0.001 \\
(0.021)\end{array}$ & $\begin{array}{c}0.028 \\
(0.018)\end{array}$ & $\begin{array}{c}0.062 * * \\
(0.024)\end{array}$ \\
\hline $45-49$ & $\begin{array}{l}-0.006 \\
(0.015)\end{array}$ & $\begin{array}{l}0.005 \\
(0.021)\end{array}$ & $\begin{array}{c}0.021 \\
(0.018)\end{array}$ & $\begin{array}{c}0.062 * * * \\
(0.024)\end{array}$ \\
\hline Black & $\begin{array}{c}0.003 \\
(0.011)\end{array}$ & $\begin{array}{c}0.018 \\
(0.017)\end{array}$ & $\begin{array}{l}0.025^{*} \\
(0.015)\end{array}$ & $\begin{array}{c}0.016 \\
(0.017)\end{array}$ \\
\hline Brown & $\begin{array}{l}-0.005 \\
(0.009)\end{array}$ & $\begin{array}{c}0.001 \\
(0.014)\end{array}$ & $\begin{array}{c}0.013 \\
(0.012)\end{array}$ & $\begin{array}{c}0.021 \\
(0.014)\end{array}$ \\
\hline Asian/Indigenous & $\begin{array}{c}0.046 \\
(0.073)\end{array}$ & $\begin{array}{c}0.048 \\
(0.090)\end{array}$ & $\begin{array}{c}0.033 \\
(0.082)\end{array}$ & $\begin{array}{c}0.108 \\
(0.070)\end{array}$ \\
\hline Fundamental school & $\begin{array}{c}0.026^{* *} \\
(0.011)\end{array}$ & $\begin{array}{c}0.039 * * \\
(0.015)\end{array}$ & $\begin{array}{l}0.023^{*} \\
(0.014)\end{array}$ & $\begin{array}{c}0.056 * * * \\
(0.019)\end{array}$ \\
\hline High school education & $\begin{array}{c}0.028 * * * \\
(0.009)\end{array}$ & $\begin{array}{c}0.106 * * * \\
(0.014)\end{array}$ & $\begin{array}{c}0.035^{* * *} \\
(0.012)\end{array}$ & $\begin{array}{c}0.085 * * * \\
(0.016)\end{array}$ \\
\hline College education & $\begin{array}{c}0.060 * * * \\
(0.015)\end{array}$ & $\begin{array}{c}0.139 * * * \\
(0.022)\end{array}$ & $\begin{array}{c}0.059 * * * \\
(0.019)\end{array}$ & $\begin{array}{c}0.097 * * * \\
(0.021)\end{array}$ \\
\hline Emotional violence & $\begin{array}{c}0.005 \\
(0.013)\end{array}$ & $\begin{array}{l}-0.002 \\
(0.020)\end{array}$ & $\begin{array}{c}0.004 \\
(0.018)\end{array}$ & $\begin{array}{l}0.006 \\
(0.020)\end{array}$ \\
\hline Physical violence & $\begin{array}{l}-0.012 \\
(0.019)\end{array}$ & $\begin{array}{l}-0.017 \\
(0.028)\end{array}$ & $\begin{array}{l}-0.006 \\
(0.025)\end{array}$ & $\begin{array}{l}-0.005 \\
(0.030)\end{array}$ \\
\hline Sexual violence & $\begin{array}{c}0.003 \\
(0.026)\end{array}$ & $\begin{array}{c}0.083 * * \\
(0.040)\end{array}$ & $\begin{array}{c}0.044 \\
(0.037)\end{array}$ & $\begin{array}{c}0.024 \\
(0.037)\end{array}$ \\
\hline Aracaju & $\begin{array}{l}-0.025 \\
(0.017)\end{array}$ & $\begin{array}{c}0.107 * * * \\
(0.022)\end{array}$ & $\begin{array}{c}0.029 \\
(0.021)\end{array}$ & $\begin{array}{c}-0.054 * * \\
(0.025)\end{array}$ \\
\hline Fortaleza & $\begin{array}{c}-0.047 * * * \\
(0.015)\end{array}$ & $\begin{array}{c}0.016 \\
(0.018)\end{array}$ & $\begin{array}{l}-0.023 \\
(0.018)\end{array}$ & $\begin{array}{c}-0.168 * * * \\
(0.025)\end{array}$ \\
\hline João Pessoa & $\begin{array}{l}-0.021 \\
(0.016)\end{array}$ & $\begin{array}{c}0.094 * * * \\
(0.020)\end{array}$ & $\begin{array}{l}0.035^{*} \\
(0.020)\end{array}$ & $\begin{array}{c}-0.017 \\
(0.023)\end{array}$ \\
\hline Maceió & $\begin{array}{c}0.022 \\
(0.018)\end{array}$ & $\begin{array}{c}0.185^{* * *} \\
(0.023)\end{array}$ & $\begin{array}{c}0.096^{* * *} \\
(0.022)\end{array}$ & $\begin{array}{c}-0.074 * * * \\
(0.025)\end{array}$ \\
\hline Natal & $\begin{array}{c}0.021 \\
(0.021)\end{array}$ & $\begin{array}{c}0.085^{* * * *} \\
(0.025)\end{array}$ & $\begin{array}{c}0.052 * * \\
(0.024)\end{array}$ & $\begin{array}{c}0.019 \\
(0.026)\end{array}$ \\
\hline Recife & $\begin{array}{c}0.005 \\
(0.018)\end{array}$ & $\begin{array}{c}0.170 * * * \\
(0.024)\end{array}$ & $\begin{array}{l}0.036^{*} \\
(0.022)\end{array}$ & $\begin{array}{l}-0.026 \\
(0.025)\end{array}$ \\
\hline Salvador & $\begin{array}{c}0.006 \\
(0.017)\end{array}$ & $\begin{array}{c}0.134 * * * \\
(0.021)\end{array}$ & $\begin{array}{l}-0.023 \\
(0.019)\end{array}$ & $\begin{array}{c}-0.086^{* * * *} \\
(0.023)\end{array}$ \\
\hline São Luís & $\begin{array}{c}-0.044 * * * \\
(0.016)\end{array}$ & $\begin{array}{c}0.087 * * * \\
(0.021) \\
\end{array}$ & $\begin{array}{c}0.021 \\
(0.020) \\
\end{array}$ & $\begin{array}{c}0.060^{* * *} \\
(0.021)\end{array}$ \\
\hline \multicolumn{5}{|l|}{ Joint significance test } \\
\hline Education variables $\chi^{2}(3)$ & $6.20 * * *$ & $26.25 * * *$ & $4.14 * * *$ & $10.26^{* * * *}$ \\
\hline Domestic violence variables $\chi^{2}(3)$ & 0.13 & 1.45 & 0.58 & 0.20 \\
\hline Mean & 0.078 & 0.207 & 0.139 & 0.778 \\
\hline $\mathrm{R}^{2}$ & 0.014 & 0.038 & 0.015 & 0.036 \\
\hline Observations & 5633 & 5661 & 5652 & 5635 \\
\hline
\end{tabular}

Robust standard errors in parentheses.

$* \mathrm{p}<0.10 . * * \mathrm{p}<0.05, * * * \mathrm{p}<0.01$ 


\begin{tabular}{|c|c|c|c|}
\hline \multicolumn{4}{|c|}{$\begin{array}{l}\text { Table B7: OLS regressions of reproductive behaviors, accounting for domestic violence in the last } 12 \\
\text { months }\end{array}$} \\
\hline & $\begin{array}{l}\text { Knows that Zika virus } \\
\text { may cause Microcephaly }\end{array}$ & $\begin{array}{l}\text { Currently } \\
\text { pregnant }\end{array}$ & $\begin{array}{l}\text { Currently using } \\
\text { contraceptive }\end{array}$ \\
\hline \multirow[t]{2}{*}{$20-24$} & 0.009 & -0.001 & -0.004 \\
\hline & $(0.011)$ & $(0.016)$ & $(0.029)$ \\
\hline \multirow[t]{2}{*}{$25-29$} & $0.022 * *$ & -0.006 & -0.030 \\
\hline & $(0.010)$ & $(0.015)$ & $(0.029)$ \\
\hline \multirow[t]{2}{*}{$30-34$} & 0.013 & -0.020 & $-0.070 * *$ \\
\hline & $(0.011)$ & $(0.015)$ & $(0.029)$ \\
\hline \multirow[t]{2}{*}{$35-39$} & 0.011 & $-0.048 * * *$ & $-0.155 * * *$ \\
\hline & $(0.011)$ & $(0.014)$ & $(0.030)$ \\
\hline \multirow[t]{2}{*}{$40-45$} & 0.012 & $-0.042 * * *$ & $-0.283 * * *$ \\
\hline & $(0.011)$ & $(0.014)$ & $(0.030)$ \\
\hline \multirow[t]{2}{*}{$45-49$} & 0.003 & $-0.056 * * *$ & $-0.394 * * *$ \\
\hline & $(0.012)$ & $(0.014)$ & $(0.028)$ \\
\hline \multirow[t]{2}{*}{ Black } & -0.002 & 0.002 & $0.039 *$ \\
\hline & $(0.007)$ & $(0.008)$ & $(0.020)$ \\
\hline \multirow[t]{2}{*}{ Brown } & 0.010 & 0.008 & $0.037 * *$ \\
\hline & $(0.006)$ & $(0.007)$ & $(0.017)$ \\
\hline \multirow[t]{2}{*}{ Asian/Indigenous } & -0.005 & 0.004 & -0.099 \\
\hline & $(0.043)$ & $(0.043)$ & $(0.101)$ \\
\hline \multirow[t]{2}{*}{ Fundamental school } & 0.011 & -0.001 & 0.021 \\
\hline & $(0.009)$ & $(0.010)$ & $(0.021)$ \\
\hline \multirow[t]{2}{*}{ High school education } & $0.027 * * *$ & -0.011 & $0.067 * * *$ \\
\hline & $(0.008)$ & $(0.008)$ & $(0.018)$ \\
\hline \multirow[t]{2}{*}{ College education } & $0.027 * * *$ & -0.015 & $0.095 * * *$ \\
\hline & $(0.009)$ & $(0.010)$ & $(0.025)$ \\
\hline \multirow[t]{2}{*}{ Emotional violence } & 0.000 & -0.014 & $0.047 * *$ \\
\hline & $(0.009)$ & $(0.009)$ & $(0.023)$ \\
\hline \multirow[t]{2}{*}{ Physical violence } & 0.001 & 0.002 & -0.034 \\
\hline & $(0.013)$ & $(0.013)$ & $(0.034)$ \\
\hline \multirow[t]{2}{*}{ Sexual violence } & -0.038 & -0.014 & -0.030 \\
\hline & $(0.024)$ & $(0.015)$ & $(0.047)$ \\
\hline \multirow[t]{2}{*}{ Aracaju } & $-0.023 *$ & 0.008 & $0.096 * * *$ \\
\hline & $(0.013)$ & $(0.012)$ & $(0.030)$ \\
\hline \multirow[t]{2}{*}{ Fortaleza } & -0.015 & 0.015 & -0.013 \\
\hline & $(0.011)$ & $(0.012)$ & $(0.028)$ \\
\hline \multirow[t]{2}{*}{ João Pessoa } & 0.002 & 0.005 & -0.008 \\
\hline & $(0.011)$ & $(0.011)$ & $(0.028)$ \\
\hline \multirow[t]{2}{*}{ Maceió } & 0.012 & 0.002 & $-0.055^{*}$ \\
\hline & $(0.010)$ & $(0.011)$ & $(0.029)$ \\
\hline Natal & 0.010 & 0.023 & $0.076 * *$ \\
\hline & $(0.011)$ & $(0.015)$ & $(0.033)$ \\
\hline Recife & -0.008 & -0.005 & -0.038 \\
\hline & $(0.012)$ & $(0.012)$ & $(0.030)$ \\
\hline Salvador & -0.005 & 0.013 & $0.052 *$ \\
\hline & $(0.010)$ & $(0.012)$ & $(0.028)$ \\
\hline São Luís & $0.020 * *$ & 0.007 & $-0.050 *$ \\
\hline & $(0.009)$ & $(0.012)$ & $(0.029)$ \\
\hline Joint significance test & & & \\
\hline Education variables $\chi^{2}(3)$ & $5.11 * * *$ & 1.36 & 7.29 \\
\hline Domestic violence variables $\chi^{2}(3)$ & 0.87 & 1.77 & 1.43 \\
\hline Mean & 0.965 & 0.043 & 0.527 \\
\hline $\mathrm{R}^{2}$ & 0.013 & 0.014 & 0.098 \\
\hline Observations & 5674 & 5406 & 5392 \\
\hline
\end{tabular}

Robust standard errors in parentheses.

$* \mathrm{p}<0.10 . * * \mathrm{p}<0.05, * * * \mathrm{p}<0.01$ 
